\title{
Developing computational approaches for the study of movement: assessing the role of visibility and landscape markers in terrestrial navigation during Iberian Late Prehistory
}

\section{Introduction}

The topic of movement in archaeology has been extensively studied. Research on human movement during prehistory has become in archaeology and anthropology one of the bases for understanding the dynamics of social and economic relationships, technology, social identity and territoriality, among many other important themes. Although archaeological investigations related to movement have increased in the last decade, the majority have usually relied on "static" evidence, that is, on the analysis of the materials or objects that are found in specific sites, establishing the relationship between them and their points of origin or destination (Branting 2004). In recent years, using spatial technologies, more research has aimed to investigate movement from a landscape perspective, in which more attention has been paid to the processes that may have happened on journeys. Some of these studies have directly or indirectly analysed the possible factors influencing the decisions about which paths to take, the mechanics of movement and the archaeological evidence related to it (Llobera 2000; Fairén Jiménez 2004; Cruz Berrocal 2004; Fábrega Alvarez 2006; Fábrega Alvarez / Parcero Oubiña 2007; Llobera / Slukin 2007; Fiz / Orengo 2008; Murrieta-Flores 20Iо, 20I2a; Mlekuž 20I0; in the current volume, Lock et al. and Mlekuž among others). In the specific case of Iberia, megalithic monuments are among the archaeological elements at a landscape scale that have been linked to potential patterns of movement, and it has been argued that, besides their symbolic and funerary meanings, they may also have been utilized as landscape markers.

The idea of prehistoric monuments as markers can be traced in archaeology to the I970 with the adoption of Saxe's (I970) Hypothesis No. 8 by researchers like Fleming (I973), Renfrew (I976) and Chapman (I98I). These authors proposed that megalithic monuments may have been used as markers with territorial connotations. Nonetheless, due to the physical and spatial characteristics of the monuments, other hypotheses have also arisen, especially in Iberian archaeology. These theories have pointed out that megalithic monuments were not only an important element structuring prehistoric landscapes, but also that they tend to sustain spatial relationships with historical pathways. This has

* University of Chester, History and Archaeology Department, UK. 
opened up the question of their possible use as markers, but with a different connotation from that of territorial definition. The idea of an association between historical pastoral routes and megaliths has been sustained not only by the strong transhumant tradition of the Iberian Peninsula, but also by the archaeological record, which points to the practice of mixed economies with an important emphasis on mobile pastoralism during late prehistory (Galán Domingo / Martín Bravo I99I-I992; Ruíz-Gálvez / Galán Domingo I99I; Criado Boado I993; Galán Domingo I993; Galán Domingo / Ruíz-Gálvez 200I; Murrieta Flores et al. 2011a; Murrieta-Flores 2012a; Murrieta-Flores 2013; Wheatley et al. 2010). These ideas have resulted in the hypothesis that megalithic monuments may indeed have acted as landscape markers, but may also have played a visual role as waypoints in terrestrial navigation during the journeys performed by these societies. Although the employment of megaliths as landscape markers during prehistory has been implied in many investigations, there has never been a specific study on Iberia to test the spatial relationships observed in the field. In addition, the concept of landscape markers has been frequently used, but never defined in the context of archaeological studies.

The purpose of this chapter is to investigate the possible role of megalithic monuments in terrestrial navigation through the development of computational methodologies using Geographic Information Systems (GIS). In order to accomplish this, we will test the hypothesis of their potential use as waypoints along pathways, using as a case study the archaeological evidence available of Copper Age (circa 3I00-2Ioo BC) societies of the mountain region of western Sierra Morena in Andalucia, Spain.

\section{Landscape markers}

The first task in testing the hypothesis of the use of monuments as landscape markers by prehistoric societies is to define what is to be understood as landscape markers. For that, it is necessary to take into account that there are many different variables and factors (social, economic and environmental) that can influence how people navigate through the landscape (Fairén Jiménez 2004; Murrieta-Flores 2010). Social relationships between groups, territorial conflicts, ideas regarding certain spaces or regions, geographical knowledge, types of terrain, time expended on travel, velocity of movement, access to basic resources while travelling and loads carried are of the greatest importance in the study of movement, as they define the routes people take. Along with these and other factors, terrestrial navigation, or the ability to orient oneself within the landscape, is essential in order to make a successful journey. That is, to follow a route, in order to get to a desired destination and to return to a point of departure, people have to acquire a series of skills. Research in experimental psychology has established that wayfinding is one of the most important of these abilities, and it consists in the process of defining and following a route from one place to another (Golledge I999). The development of this skill is possible thanks to the creation of 
cognitive maps, which allow the construction of mental representations of the ideas that we hold regarding space and places, the environmental features that can be perceived and the spatial connections and relationships that they sustain (Murrieta-Flores et al. 20Irb). Thus, to carry out a journey, the traveller will have to establish points of origin and destination, know the places where he/she needs to deviate, be able to recognize spatial markers and understand the complete route within a larger frame (Murrieta-Flores 20I0). Therefore, the recognition of outstanding features in the landscape, or waypoints, plays a fundamental role in human movement (for a complete discussion on the theory and definition of landscape markers see Murrieta-Flores 20Iıb; 20I2b).

\section{Megaliths as waypoints in Iberia}

Although it has been generally accepted that the emergence of megalithic tombs seems to be related to the first evidence of a wish by communities to delimit their space, in the case of Iberia they have also been associated with crossing places and markers (Galán Domingo / Martín Bravo I99I-92; Andrés Ruperéz I999; Galán Domingo / Ruíz-Galvez 2001, 264; Gómez Vila 2005, 407). Therefore, mobility has been considered one of the main variables influencing the location of mounds and megaliths, suggesting that they may have been used as waypoints (Criado Boado et al, 1994, 39).

Observations giving support to this theory have been made since the Iوth century, when Silvelo (I887, in Gómez Vila 2005, 406) affirmed that megaliths were found along Roman paths, and that they were normally positioned on both sides of the road. Later, as a consequence of early research tracing the Antoninan route, Diaz Sanrujo (I906, in Gómez Vila 2005, 406) stated that the presence of megalithic monuments was a strong indication of the existence of ancient paths, arguing that the most favourable crossing places in a watershed would be the ones with megalithic monuments nearby. He also declared that this assertion was so accurate that new roads were actually being constructed by identifying these places. Later, during the early 2oth century and after some decades of discussion of these theories, Maciñeira (I943 and I947, in Gómez Vila 2005, 407) documented 87 monuments along $40 \mathrm{~km}$ of both sides of the Camino Real (royal pathway), and found traces of wheel tracks in various sections of the excavation along the road. In his report, the author not only argued that there was a relationship of intervisibility between the monuments and the road, but also concluded that, in a landscape with little vegetation, these monuments were in fact acting as waypoints along the route. More recent spatial analyses have also led to the conclusion that megalithic monuments were associated with pastoral activities due to their spatial linkage with transhumance routes (Criado Boado et al. I990-91; Criado Boado et al. 1994, 39; Galán Domingo / Ruíz-Galvez 200I; Murrieta Flores 2007; Wheatley et al. 2010; Murrieta-Flores 2012a).

This association seems particularly important in terms of terrestrial navigation, as transhumant pastoralism constitutes a strategy that involves the movement of cattle, travel- 
ling long distances between different altitudes to undertake seasonal exploitation of pastures in the mountains during the summer and the pastures of the lowlands during the winter (Ehlers / Kreutzman 2000, I6). This activity is recorded in Iberia in medieval times and, although it has been argued that its practice during prehistory is improbable because it was a specific phenomenon produced by the historical circumstances of the Middle Ages (Chapman I979; Walker I983), it can be suggested that short-distance transhumance (also known as trasterminancia) was possible. At the same time, other studies have emphasized that the monuments seem not to be related exclusively to historical routes, but also to transit zones in general. Research carried out in Aranga, Monfero, La Coruña and Lugo (Galicia) has established a linkage between mounds, paths and privileged communication zones (Criado Boado I99I; Criado Boado et al. I990-I99I, 33-34; Eguileta Franco I994; Villoch Vázquez 200I; Gómez Vila 2005). The region of Cantabria has also been prolific in terms of observed associations between menhirs and passageways in watersheds such as Collado de los Sejós (Santander) (Bueno Ramírez et al. I985). A similar association has been observed for megalithic monuments in the Tajo River Basin (Galán Domingo / Martín Bravo I99I-I992), where their location seem to be related to vados or fords along the river. In this sense, although some of the evidence collected up to now indicates that megalithic monuments were located at the sides of possible transhumance routes, in other cases it seems clear that megaliths were also located at crossing points, perhaps acting as "nodes" or waypoints along routes, marking or commemorating a specific locus of transit or spots where rivers can be crossed.

The location of the monuments is only one of the qualities observed that is deeply related to the theories of why and how megaliths played the role of landscape markers. Monumentality is another of the characteristics that have led archaeologists to conclude that such a use is possible. Prehistoric societies seem to have maximized this effect, constructing the monuments in visible or prominent points of the landscape such as hills or crests. In some examples it seems that they even enhanced their visibility, using white quartz for their construction (Bueno Ramírez I987). However, monumentality as a characteristic of megaliths in their use as landscape markers is difficult to assess, as there is a difference or variability in the investment devoted to the construction of these monuments in different parts of Europe. In terms of movement, differences in monument size probably had repercussions in the way a traveller perceived or understood the landscape and, therefore, the role of the monuments in mobility.

In any case, it is beyond reasonable doubt that megalithic monuments were constructed to be noticed by people and to remain as part of the memory of groups and the landscape for generations. For these societies, megalithic monuments (funerary or ritual) constituted established milestones. As such, not only were they present in the social imagination through their communal and symbolic connotations, but, because of their monumentality, they also formed part of society's physical reality as principal components of their established landscape. In terms of research, although the concept of the use of mega- 


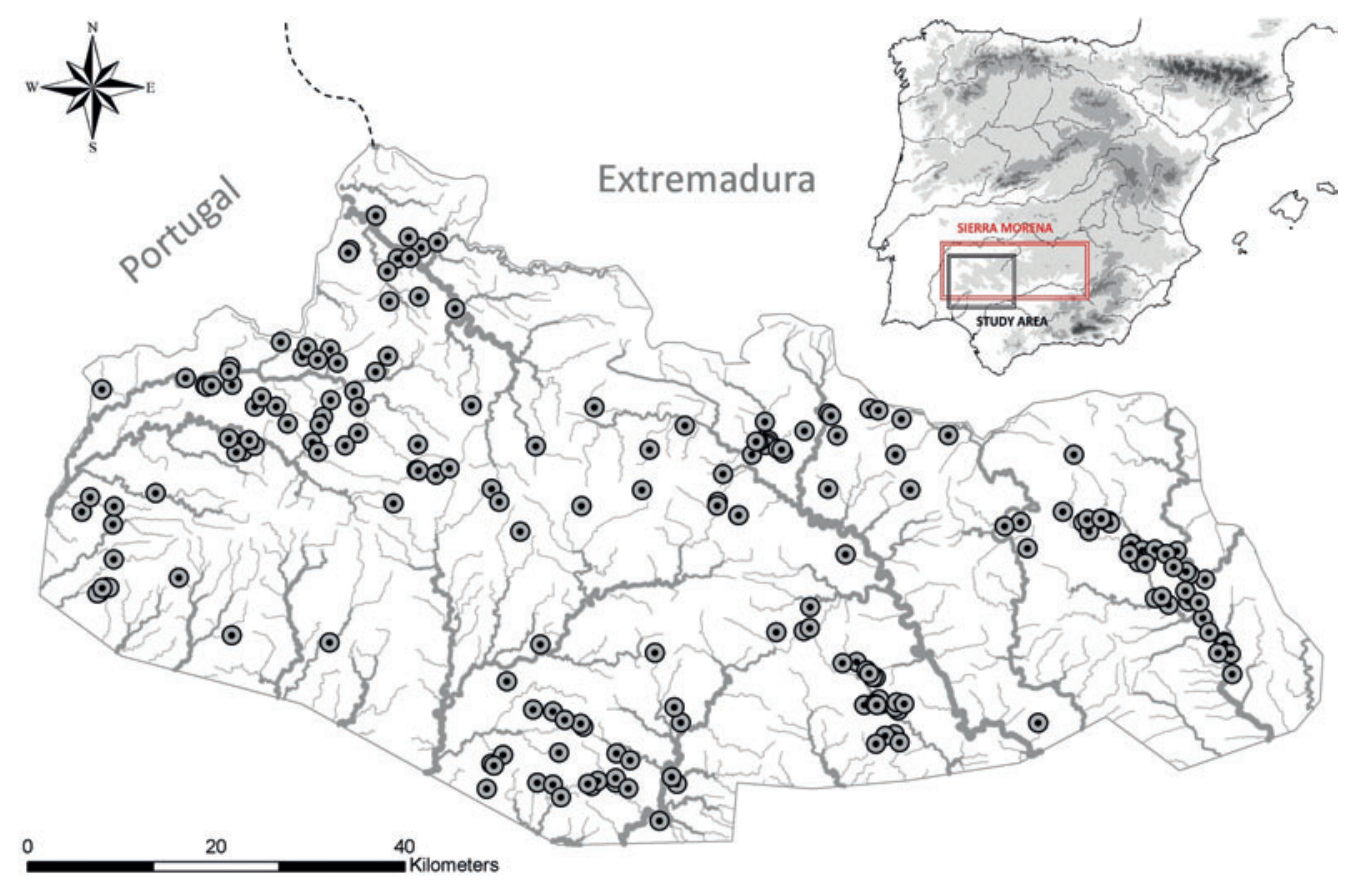

Fig. 1 Situation of Sierra Morena in Iberia; western Sierra Morena and all the Copper Age sites recorded.

liths as landmarks or waypoints has been explored mainly from a theoretical point of view, it remains necessary to implement robust methodologies in order to establish whether different dynamics in their use can actually be observed. As a case study, we selected one of the most important mountain regions in Iberia.

\section{The case of western Sierra Morena}

Sierra Morena is a mountain range which constitutes the zone of contact between the Spanish Central Plateau and the Betic Depression and which crosses the northern extreme of Andalusia, covering $400 \mathrm{~km}$ from east to west (Figure I). It is located between two of the most fertile agricultural river valleys of southern Iberia (Gualdalquivir and Guadiana), and it has been characterized by its richness in terms of mineral resources, but also by its extreme poverty in terms of agricultural potential. In recent years, this region has been the subject of a range of diverse projects aiming to understand the settlement patterns and the megalithic phenomenon (Pellicer Catalán / Hurtado Pérez i980; Piñón Varela I987; I988; Martínez Rodríguez / Lorenzo Gómez i992; Pérez Macías i983; 1986; 1987; 1994; 1996; I996b; I996c; I999; 2010; García Sanjuán et al. 2002; García Sanjuán / Vargas Durán 
2002; García Sanjuán et al. 2004; García Sanjuán et al. 2006; Hurtado Pérez et al. 201I). Thanks to these studies, a more complete picture of the societies that inhabited this mountain range has been acquired.

The region of western Sierra Morena (comprising Sierra de Huelva and Sierra Norte de Sevilla), has come to be of particular interest due to the fact that societies during Late Prehistory, and especially during the Copper Age (3100-2100 BC), seem to have had not only a different kind of access to resources compared with those in the valleys, but also an alternative social organization. According to the studies of settlement pattern, during this period there was a general growth of population, and new settlements were also established in places where there were none before and different kinds of habitats were apparently used, ranging from larger settlements to apparent seasonal camps. On a regional scale, western Sierra Morena acts in many ways as a kind of border area with respect to its surroundings. In terms of its material culture, and mainly in its pottery, the Chalcolithic sites of western Sierra Morena seem to share many characteristics with those in the Guadalquivir Valley, eastern Andalusia and the southwest in general (Pérez Macías i994, 4). However, its difference from the neighbouring regions seems to be more related to the particular environment of the sierra; this is reflected in the subsistence activities, which are closely tied to mobile herding, due to the almost non-existent potential for agricultural activities, in contrast to the mainly agricultural character of the adjacent valleys.

From the 388 sites recorded by various projects in the area of the western Sierra Morena, II3 megaliths and megalithic cists have been included in the study. Only a few menhirs (4) and sites with rock art (2) have been recorded; although it is known that they are not the only ones in existence, they are the ones with exact co-ordinates available.

\section{Assessing the use of megalithic monuments as markers through visibility analyses}

As explained before, several theories to explain the observed empirical association between megalithic monuments and pathways have been discussed in recent years. In the specific case of western Sierra Morena, pastoralism probably started in the Neolithic, and the need for pasturage may have been one of the main motors for movement. Recent research has concluded that late prehistoric societies of this region probably practised short-distance transhumance and that their symbolic sites were deeply related to their dynamics of movement (Murrieta-Flores 2007; 20I2a). These studies have also recorded a strong spatial relationship between monuments and herding pathways, pointing to the possible role of these sites as stations in pastoral orbits. As important spatial markers, one possible explanation for this observed relationship is that monuments could have served as waypoints for terrestrial navigation during the transhumant cycles. As explained before, megalithic monuments offer all the characteristics desired in a landscape marker, not only through their distinctive shape and size, but also because of their deep symbolic and social importance. 
To test if they could have been used as waypoints we can make use of GIS visibility analysis. As observed above, there are many factors that may influence how humans move. However, one of the main and most important prerequisites for navigating while travelling is the use of vision. Visibility becomes a critical factor in terrestrial navigation because it is through vision that we can identify the markers or waypoints (including celestial bodies) that will allow us to take decisions regarding the next direction to take while travelling. In this sense, in order to investigate if the megalithic monuments could have acted as waypoints, we need to establish if they were actually visible along possible travelling routes rather than merely close to them. The visibility of the monuments becomes essential as, in this case, the possible spatial relationships between waypoints and travellers (and therefore the cognitive maps that are constructed) are generated in a dynamic way as the observer moves along a route. The specific aim of the experiment presented in this chapter is thus to investigate a possible visual structuring of the landscape in relation to the monuments, by means of a visibility study that analyses the relationships between natural corridors and the monuments as the traveller moves along the paths.

Although this seems straightforward in a sense, it is necessary to take into account two specific considerations in our case study. Firstly, due to the observed close spatial relation that the monuments sustain with natural corridors (Murrieta-Flores 20I2a), the visibility patterns that we may detect could be product of a cross-correlation. That is to say, they might be visible from the corridors because they are close to them, or, on the other hand, they might be close because from those positions they are visible. Both connotations have important implications for the interpretation of the patterns left by these societies. In the first case, it could imply that the monuments were built along the paths for practical reasons, like easy transport of building materials, for instance; in the second case, it could imply that the monuments were located near to the pathways with the purpose of being visible, due to symbolic or traditional activities like ceremonial processions or marking stations within herding orbits. Although this is a complex question that will not be solved in this study, the following analyses provide some pointers towards fresh ideas. The second consideration that needs to be taken into account is that many aspects of terrestrial navigation are deeply related to movement. While it is possible to confirm through a GIS-based visibility analysis whether the monuments are visible from the routes or not, mapping the visual changes that occur within the landscape in those terms will not necessarily reveal specific perceptions of the landscape while travelling. ${ }^{\mathrm{I}}$ Nevertheless, features created purposefully for terrestrial navigation usually tend to be strategically located to be as visible as possible. In this sense, we can not only explore how constant the view of a monument is within the rate of visual change along a route, but we can also identify those locations on which one or more features have a visual impact. This can help us to understand the visual

I For an extended discussion of this and other difficulties such as the role of vegetation, etc., see MurrietaFlores, 20I2b. 


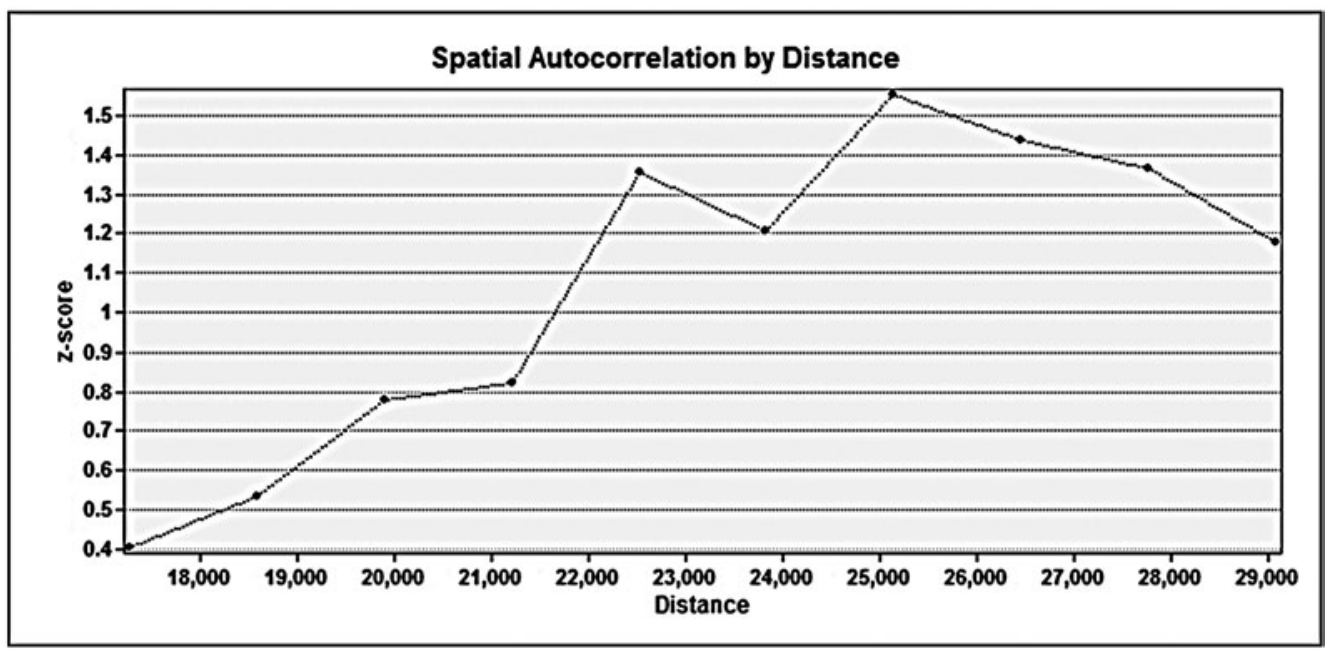

Fig. 2 | Moran's I-Z Score of the megalithic monuments.

structure of the megaliths from corridors, allowing us to detect whether there was an intentionality behind the location of these monuments that could be related to both visibility and movement.

\section{Constructing visibility methodologies: \\ Parameters and technical development of the analyses}

As said above, visibility is subject to important factors related to scale, such as distance. Because visibility decays with it and due to the fact that to navigate people have to be within a "close" range of a waypoint in order to see it, a sub-regional scale was chosen to carry out this experiment. Following the recommendations made by Wheatley and Gillings (2002, 209) regarding the selection of study areas, it was decided to perform spatial statistics to divide the entire region into groups of monuments.

In order to select the study sub-regions, a Kernel Density Analysis was carried out. This method is used to calculate the magnitude per unit area of points, identifying possible clusters. In this analysis it was considered of importance to establish an appropriated neighbouring search radius, because it influences how the kernel density is performed. In order to do that a spatial autocorrelation test (Moran's I) was carried out, establishing a statistically significant radius to carry out the kernel density. From the results obtained in the Moran's I test, the peak of the Z score (which measures how intense the cluster is) was chosen and used as search radius for the Kernel Density analysis (Figure 2). The output indicated five major clusters. In reality the Aroche area (western cluster) shows a more con- 


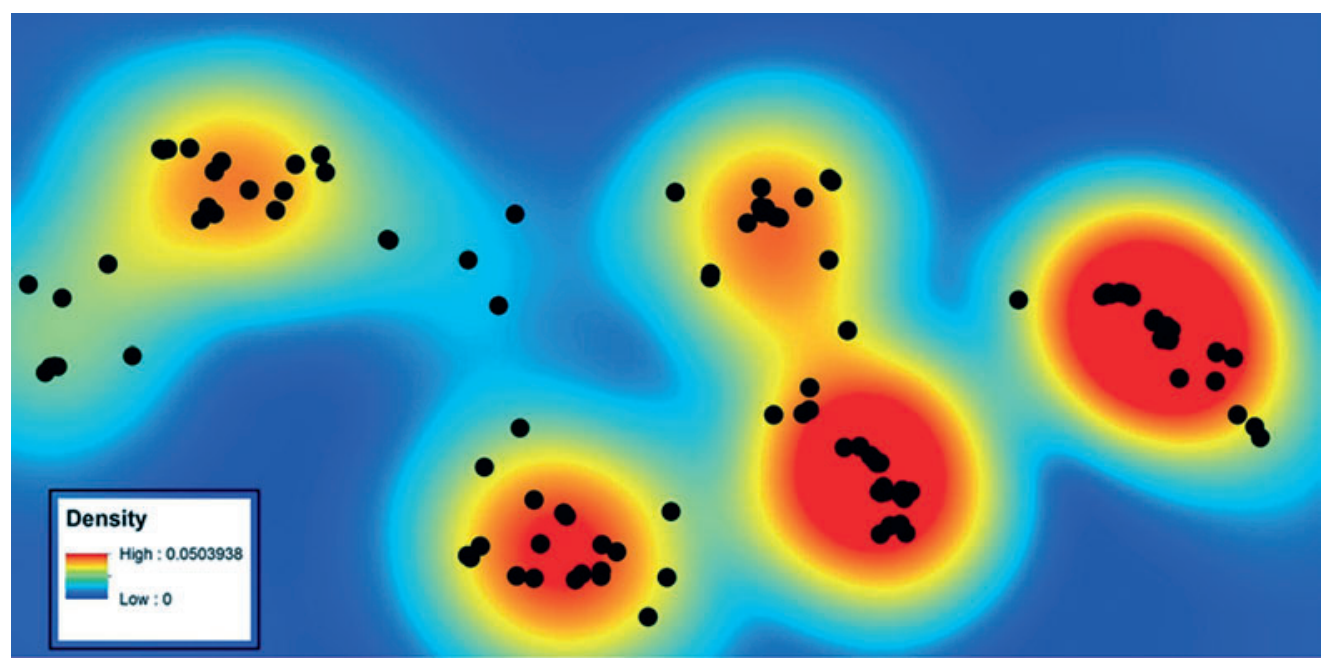

Fig. 3 | Result of the Kernel Density for the definition of clusters.

sistent concentration in its northern part, and for this reason, as well as for analytical purposes, it was decided to derive a sixth group (Figure 3).

In this manner, the sub-regions established are: Almadén de la Plata (Group I), Castillo de las Guardas (Group 2), Aracena (Group 3), Zalamea la Real (Group 4), Aroche (Group 5) and Santa Bárbara de Casa (Group 6). It also has to be noted that the region of the Murtigas River could not be considered within this analysis due to the fact that there is only one monument recorded in that area (Figure 4).

For the visibility analyses and in order to approximate more accurately human vision, the vertical angle range considered was between +IO and -I5 degrees, as suggested by the results of some physiological studies consulted (Ogburn 2006). In terms of the visibility range, while in optimal conditions it has been established that a range between $23-39 \mathrm{~km}$ is acceptable (Ogburn 2006), in management and archaeological studies the visual ranges used have been more conservative (I5-18 km and 3-6 km respectively) (Wheatley I995; García Sanjuán et al. 2006). We decided to use a threshold of $3 \mathrm{~km}$, assuming a theoretical maximum viewshed of $28.2 \mathrm{~km}^{2}$.

As said above, the idea behind this experiment was to test if the megalithic monuments could act as waypoints for terrestrial navigation. According to the theory developed on landscape markers (Murrieta-Flores et al. 20IIb; Murrieta-Flores 20I2b), to fulfil this condition, monuments are expected to present one or more of the following characteristics:

(I) they should tend to be considerably visible from the natural corridors or passageways,

(2) the dominant direction of their fields of view should be those orientated towards the natural corridors, and 


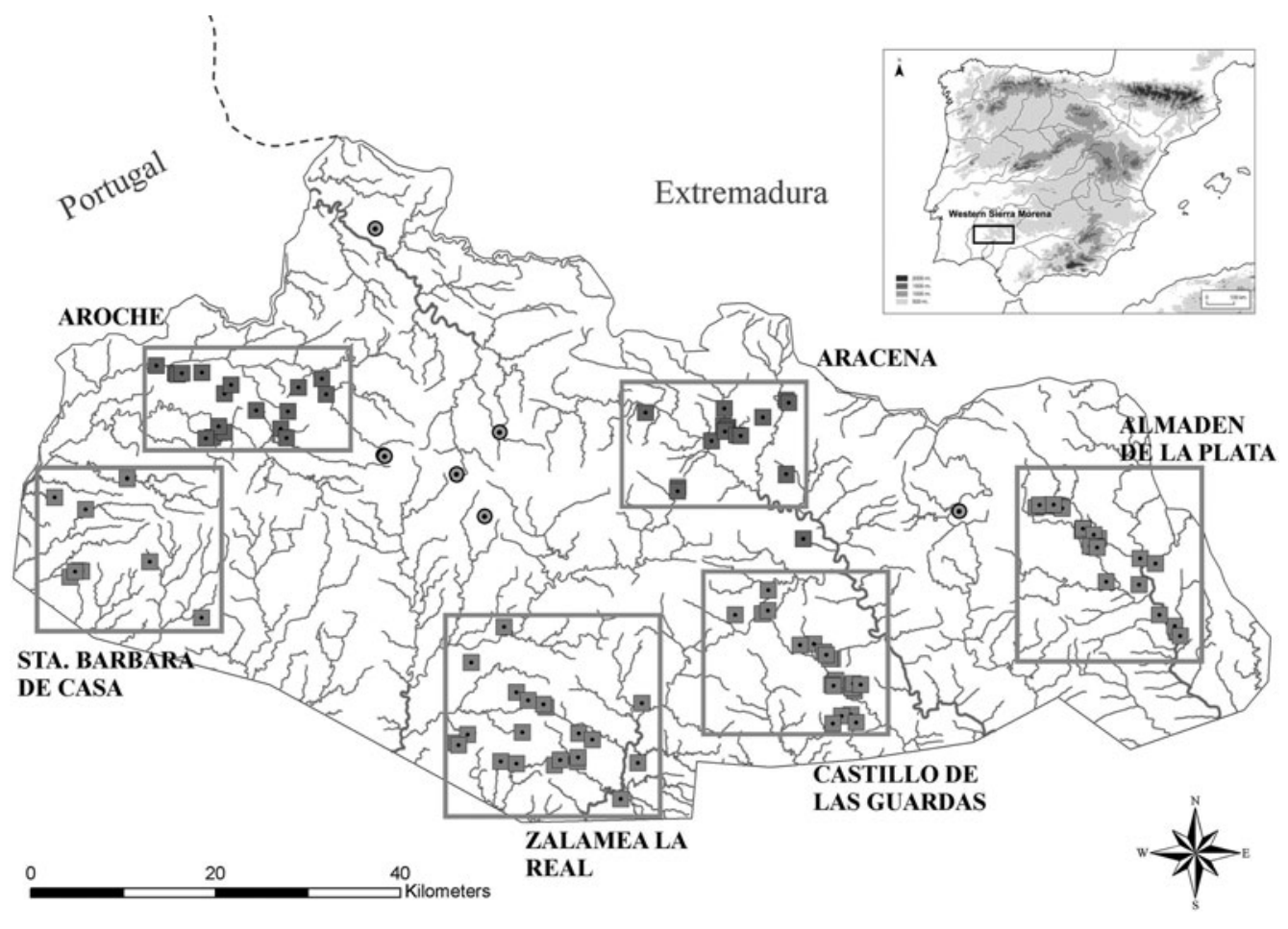

Fig. 4 | The 6 groups defined for the visibility analyses.

(3) they should be located in a distance range from the corridors that makes them more likely to be visible and therefore used as waypoints.

In order to test these ideas, three different spatial analyses were developed.

In the case of the first characteristic - that the monuments should tend to be highly visible from the natural corridors or passageways - a binary viewshed analysis could be used to simply test whether monuments are visible or not from natural corridors. ${ }^{2}$ However, if they are also visible from many other locations within the landscape, their visibility may not be regarded as a determinant attribute in their role as waypoints for terrestrial navigation. This is not to say that in order to function as landscape markers, the monuments should only have to be visible from the routes. However, if they acted as waypoints, a closer visual relationship between monuments and routes could be expected than between any random point in the landscape and routes. In order to test this, we conducted viewshed analyses and documented the parts of the natural corridors from which the monuments are visible

2 These corridors were established in a previous study that also used GIS methods; the full documentation of their calculation can be consulted in Murrieta-Flores $20 \mathrm{I2}$. 


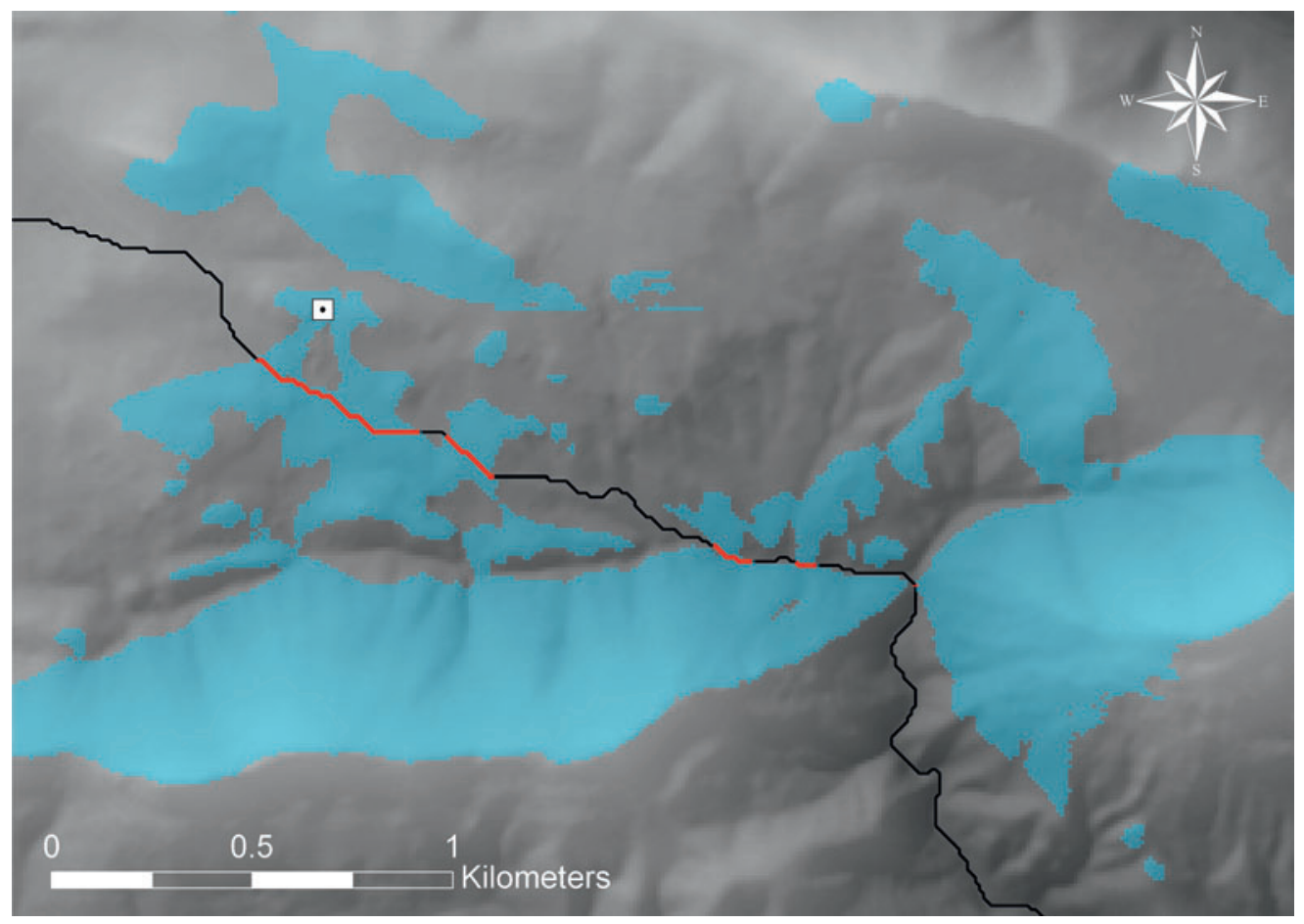

Fig. 5 | Segments of the natural corridors from which a particular monument is visible (in red). Dolmen de Gabino in Almadén de la Plata.

(Figure 5). The same was done with a sample of random points, and later both cases were compared through a statistical test of significance. The purpose of this was to establish if there is a difference between the two samples. The idea behind this is to investigate whether the monuments occur in locations that are more visible from the natural corridors than would be expected by chance alone.

The test chosen was the Kolmogorov-Smirnov test and it involves the comparison of the cumulative frequency distributions of the two independent samples. In this case the null hypothesis set for all groups was: $\mathrm{Ho}=$ The megalithic monuments are randomly distributed with respect to their visibility from natural corridors. Following the method described, a total of six tests were conducted at a significance level of 0.05 , assessing each of the sub-regions established.

These procedures were set as the base analysis in order to explore whether we can observe significant relationships between the visibility of the monuments and the corridors. In addition to this, with the record of the segments of corridors from which the megaliths are visible, it was possible to explore certain characteristics between these parts of the landscape and the monuments. In this manner, profiles of the visual exposure to monuments 
from corridors were also produced from the visibility analysis. This was aimed at graphically visualizing the continuity in the visibility of monuments along the corridors, and to quantify in each of the sections how many megaliths might have been visible at the same time (Figure 6).

In the case of the second characteristic to be explored - that the dominant direction of the monuments' fields of view should be those orientated towards the natural corridors an analysis investigating the possible dominant directionality in the fields of view of the monuments was carried out to assess whether these are in places that favour or promote their visibility from the routes or, in other words, whether there is a pronounced directionality in their fields of vision that promotes a visual relationship with natural corridors. The method followed here is the one proposed by Wheatley and Gillings (2000). The analysis consists in the calculation of a simple binary viewshed of the viewpoint (the monuments in this case), the calculation of its Euclidean Direction, then the reclassification of this raster into directional zones (N, NE, E, SE, S, SW, W and NW). Finally, the binary viewshed is overlaid with the reclassified Euclidean direction in order to quantify the dominant directionality in the viewshed (Figure 7).

A table with the results of this analysis was created for each group in order to quantify the predominant directions of view of all monuments. Once the dominant directions for each megalith were identified, it was examined whether a natural corridor passed through it or not. This was used to calculate the percentage of monuments whose main direction of view is oriented towards a natural corridor. In order to investigate if the coincidence observed between them could be a matter of chance, a I-sample Chi-square statistical test was also conducted. The purpose of this was to identify in a robust way any possible pattern of visual structuring that might indicate a preference for locating the monuments in places that favoured visibility towards and/or from corridors. In this case, a null hypothesis was formulated as: $H o=$ The natural corridors are equally distributed across dominant and nondominant fields of view of the monuments. The test was carried out at a significance level of 0.05 .

To test the third characteristic mentioned - that the monuments be located in a distance range from the corridors that makes them more likely to be visible and therefore used as waypoints - a Higuchi viewshed analysis was conducted. However in this case, instead of using the distance index proposed by Higuchi (1988), we created particular ranges for our study areas that take into account field observations and the experience of Llobera's study (2007b). Higuchi's example was adopted for this experiment in terms of the methodology followed to establish distance ranges (measuring the angles that a particular object occupies in a field of view, and deriving the distances from this). However, instead of using as reference a natural element such as trees, we decided to take an archaeological element, in this case the megalithic monuments. This was thought to be more appropriate, because we are interested particularly in the effect of distance on the visibility of monuments and not on the general landscape. 

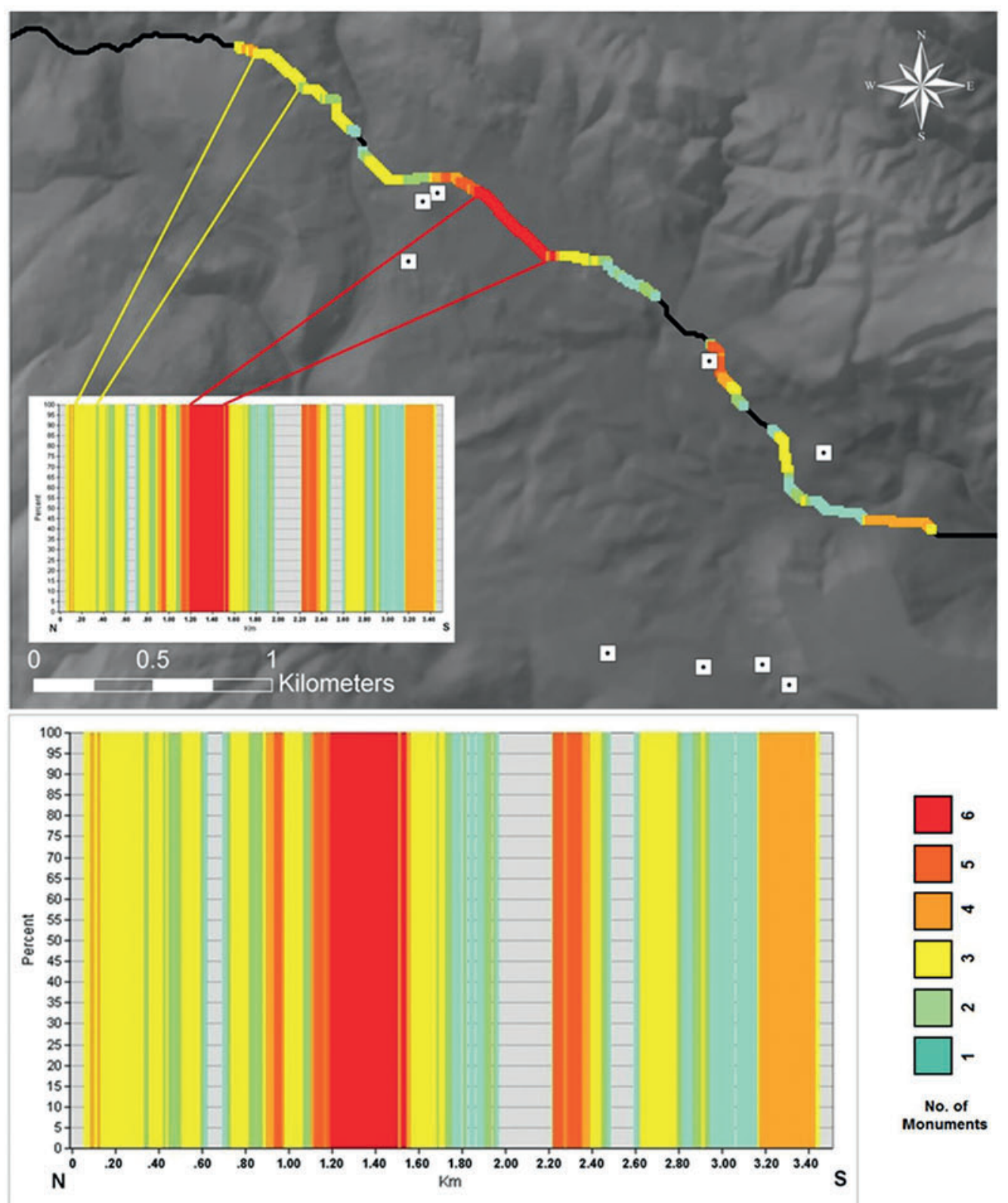

No. of Monuments

Fig.6 | Example of the profile of visual exposure to monuments from a route in Almadén de la Plata. 

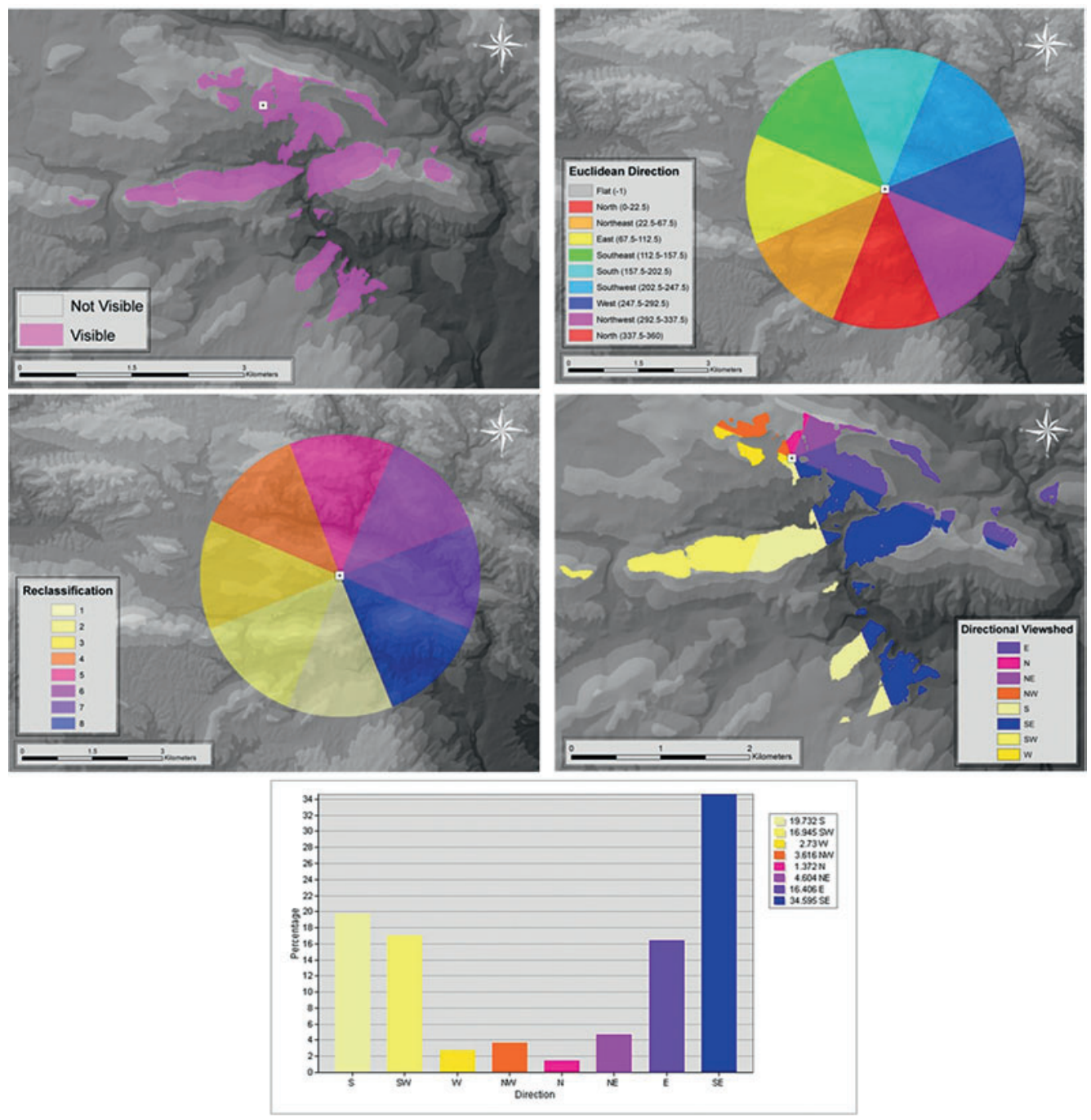

Fig. $7 \mid$ a) Simple binary viewshed; b) Calculation of Euclidean Direction; c) Reclassification of Euclidean Direction; d) Overlap of viewshed and direction; e) Graphic showing the predominant direction of the viewshed. 

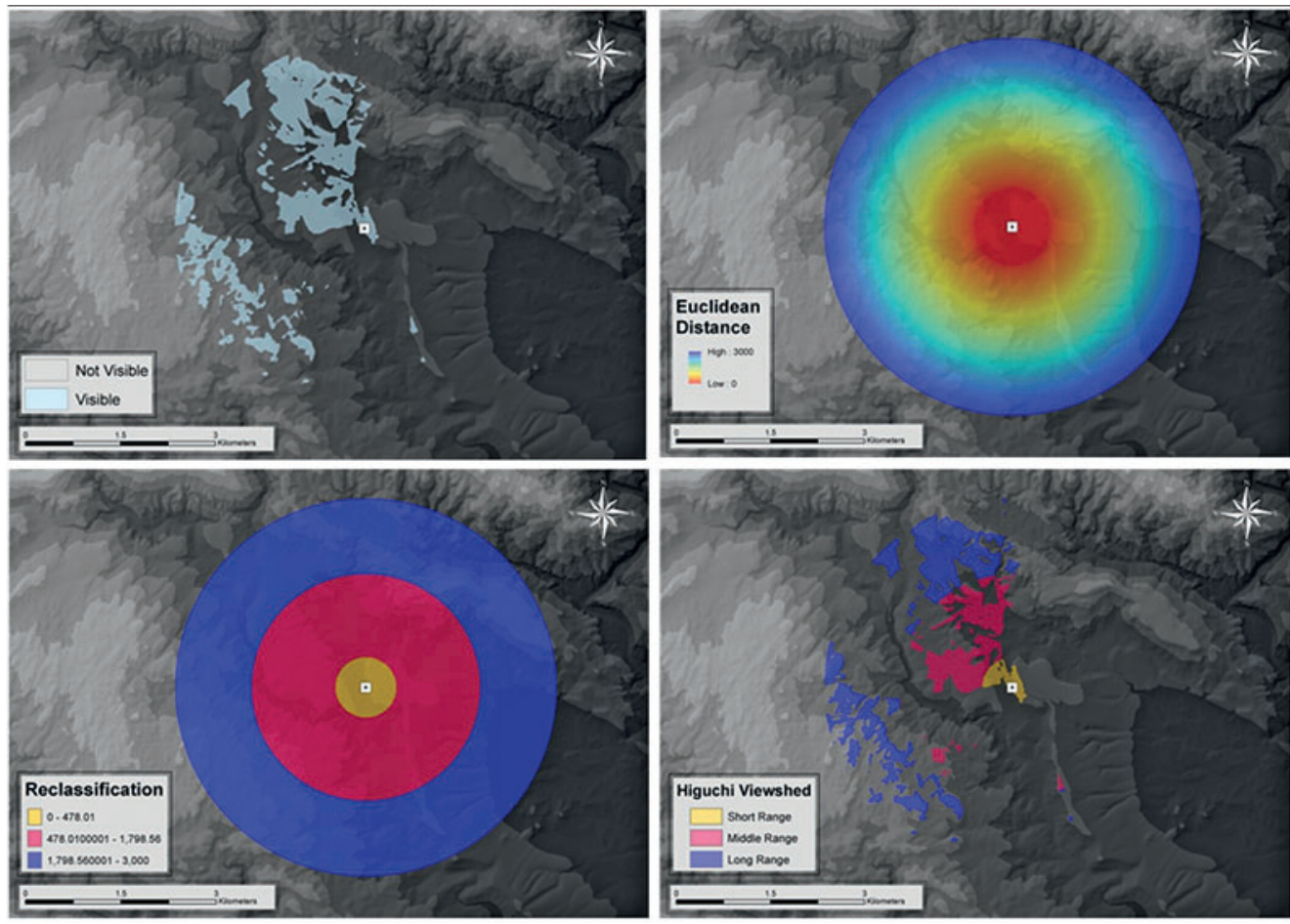

Fig. 8 | Procedure to generate a Higuchi viewshed: a) Binary viewshed; b) Calculation of Euclidean Distance; c) Reclassification to the index established; d) Combination of both.

The method proposed by Wheatley and Gillings (2000) was followed, but particular distance ranges were adopted in this case. The analysis consisted in the calculation of the viewshed from the point of interest and its classification into meaningful distance ranges. The classification used in this case is based on a field experiment conducted by looking at a particular monument and its integration into the general landscape. This was done in a similar way as Higuchi did in the case of trees, and Llobera (2007b) in the case of monuments. Taking a monument with a height of $2.5 \mathrm{~m}$, the visual angle that occupies the monument in the field of view of an observer was measured, establishing alpha $(\alpha)$. The distance ranges were calculated according to the field observations, taking into account that the closer the observer, the wider the angle (Figure 8). The method followed has been described elsewhere (Murrieta-Flores 20I2b) and it is sufficient to say that the angles were measured with an inclinometer. In this manner, the ranges were defined as follows:

Short Range: $\alpha$ larger than $0.3^{\circ}$. Activities closely related to the monument probably happened at this range. At a larger scale the monuments act as reference points in the landscape, they are very well defined and their shape can be easily identified. A person can be recognized effortlessly in their surroundings. 


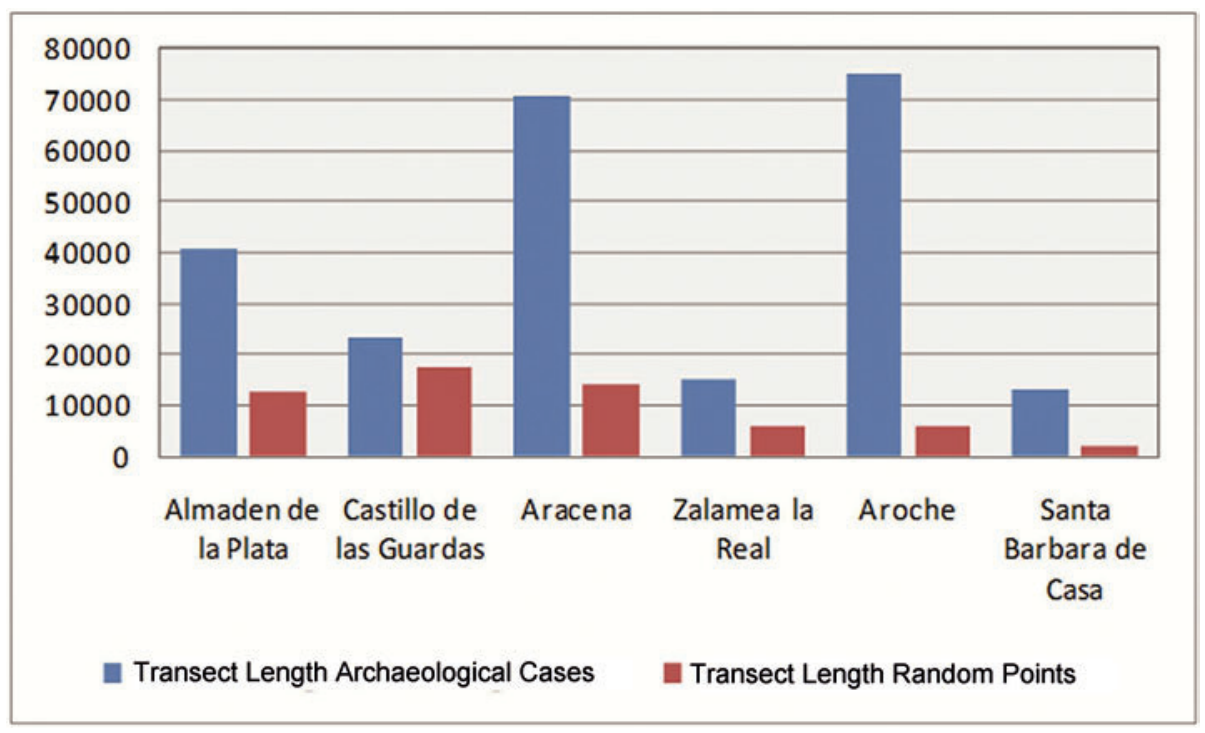

Fig. 9 | Comparison between the lengths $(\mathrm{m})$ of the path segments from which the monuments or random points are visible.

Middle Range: $\alpha$ from $0.08^{\circ}$ to $0.3^{\circ}$. The monument can still be a reference point but is likely to appear more integrated into the wider landscape.

Large Range: $\alpha$ less than $0.08^{\circ}$. Although the monument may still be visible, it may start to fade into the surroundings. How easily it is recognized will probably depend on the actual shape of the monument or its contrast with the surrounding landscape.

In this sense, the maximum distance in the Short Range will be 478 . o I $\mathrm{m}$, in the case of the Middle Range it will be I,798.56 $\mathrm{m}$ and the limit of the Large Range will be defined by the distance established in the actual visibility analysis, which in this case is 3,000 $\mathrm{m}$.

\section{Results}

The results obtained from the statistical tests were very interesting in terms of observable patterns. From the six tests (one per group) conducted to investigate if megalithic monuments are randomly distributed with respect to their visibility from natural corridors, in three cases the null hypothesis was rejected at a significance level of 0.05 . While the groups in this situation were Almadén de la Plata (Group I) (25 monuments), Castillo de las Guardas (Group 2) (22 monuments) and Aroche (Group 5) (I8 monuments), whereas for Aracena (Group 3) (I6 monuments), Zalamea la Real (Group 4) (29 monuments) and Santa Bárbara de Casa (Group 6) (9 monuments), the null hypothesis could not be rejected. 
Although this appears at first sight to be an inconclusive result, delving into the results of the analysis we see that in all cases the megalithic monuments are on average more visible from the natural corridors than from random points in the landscape. This is demonstrated by comparing the visibility of the random sample and the monuments, where it can be observed that the length of segments from which they are visible is more extensive (Figure 9).

Even in the groups where the null hypothesis could not be rejected, the megalithic monuments were visible for longer sections than the random points. In the case of the Aracena group, while the total length of segments from which the random points are visible is $13,951.293 \mathrm{~m}$, the total length from which the megalithic monuments are visible is $70,550.484 \mathrm{~m}$. In the case of Zalamea la Real, the same phenomenon is observed, where the total length of the corridors from which the random points are visible is $6,040.666 \mathrm{~m}$, and I3,303.II4 in the case of the megalithic monuments. For Santa Bárbara de Casa the difference is also large, with a total length of 2,120.460 $\mathrm{m}$ for the visibility of random points, and I3,184.366 $\mathrm{m}$ for the monuments (Figure I0). This means that in general there is a larger visual exposure of the megalithic monuments along the natural corridors than other points in the landscape, even if we cannot say that the relationship is statistically significant at a 0.05 level.

This is obviously connected to the already proved spatial relationship between monuments and corridors and it could be thought of as an indication of their use as waypoints. However, if the megalithic monuments were acting as such for travellers who were not necessarily familiar with the landscape, and their locations were intended as terrestrial guidance, they should have acted as a relatively regular system. In other words, along the route at least one of the monuments would be visible at all, or almost all, times. This is related to the way terrestrial navigation is accomplished, where in order to follow a route we need to be able to connect spatially the diverse markers on the route. In order to test this, the visual exposure to the megalithic monuments along the routes was graphed, measuring for how long segments have a visual exposure to the monuments in each group. For this, the number of monuments that are visible each $10 \mathrm{~m}$ along a path was recorded, generating a visual graphic of its exposure to them (Figures II and I2).

Although in this chapter only some examples are presented, it can be noted that, in most of the groups, visual exposure to the monuments along some of the routes was detected. Nonetheless, there tend to be considerable "gaps" in the visual exposure from routes. This contradicts the notion of a visual network. However, a positive outcome is that the analysis allowed the identification of sections on the pathways that seem to have prompted the visibility of a large number of monuments. This can be regarded as significant in terms of the visual impact that megaliths and other prehistoric monuments (such as Bronze Age stelae) may have had within the landscape (García Sanjuán et al. 2006; García Sanjuán 20II), and the establishment of symbolic places possibly related to specific groups. In this manner, the continuous visibility of these monuments from the paths emphasizes 

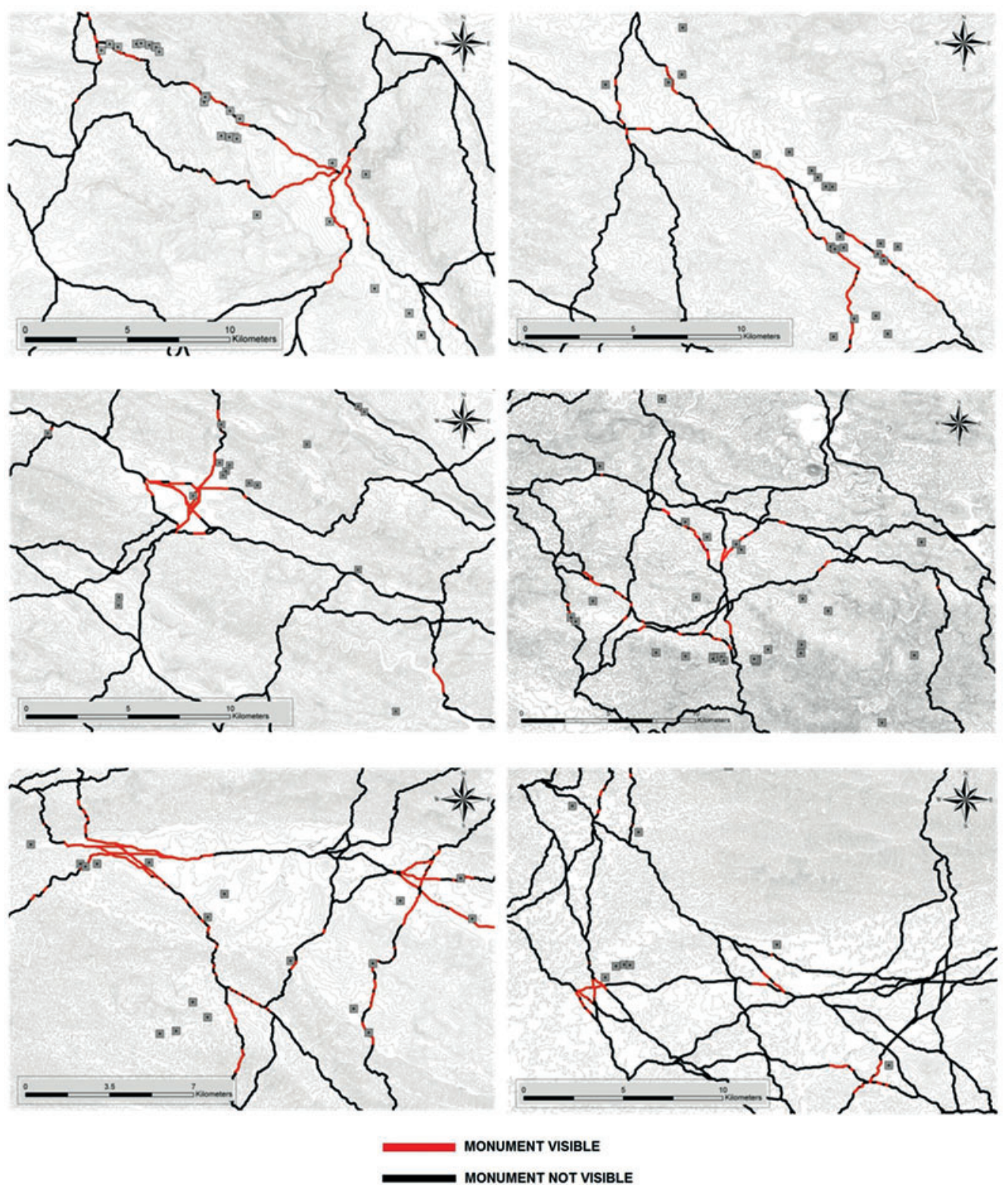

Fig. 10 | Segments of the natural corridors from which one or more megalithic monuments are visible: a) Almadén de la Plata, b) Castillo de las Guardas, c) Aracena, d) Zalamea la Real, e) Aroche and f) Santa Bárbara de Casa. 

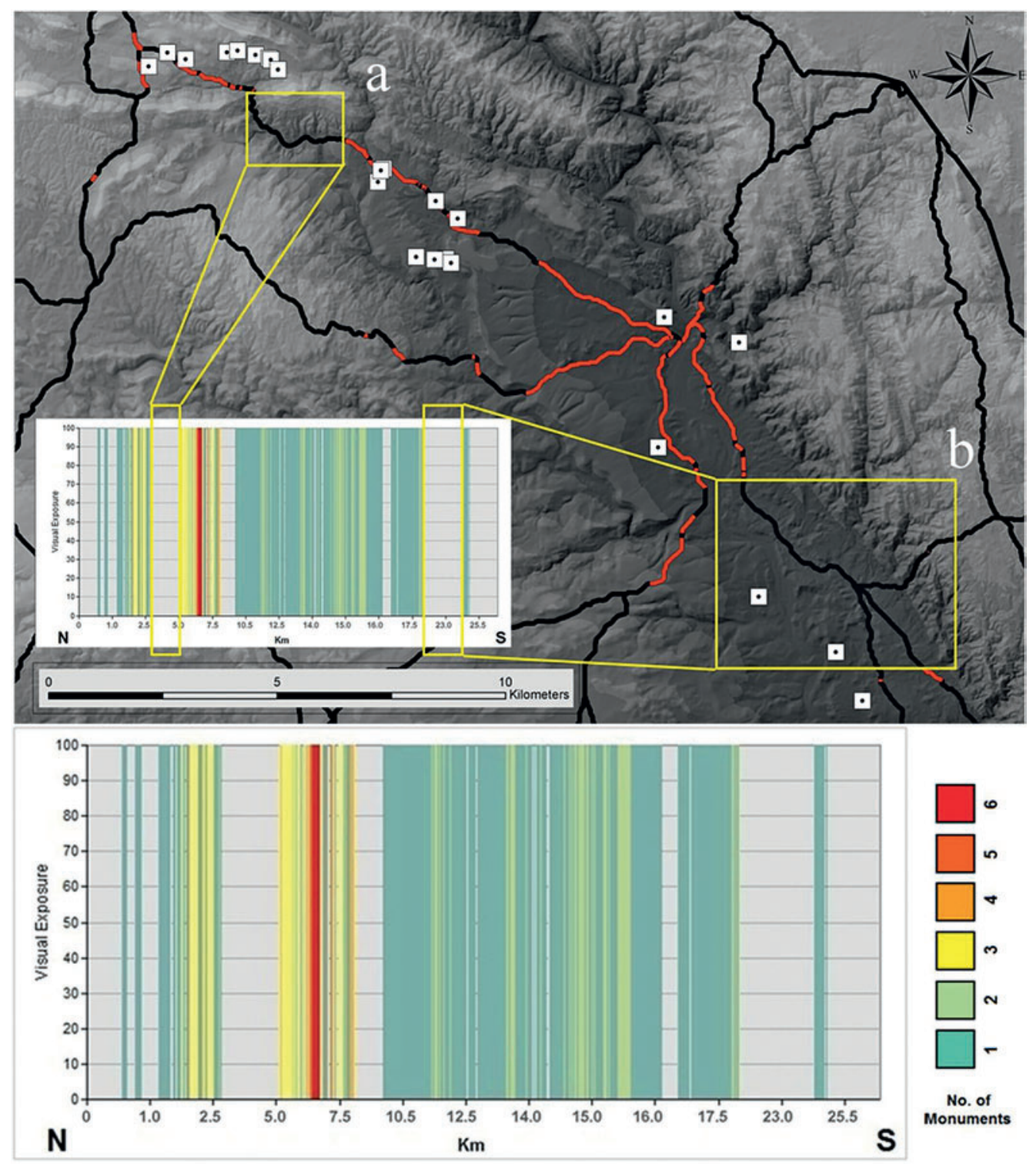

No. of

Monuments

Fig. 1 | Cumulative visual exposure to megalithic monuments from natural corridors of Almadén de la Plata and the longest gaps in visual exposure between (a) the San Bartolomé and Palacio groups and (b) El Chaparral III and Dolmen del Esparragal. 

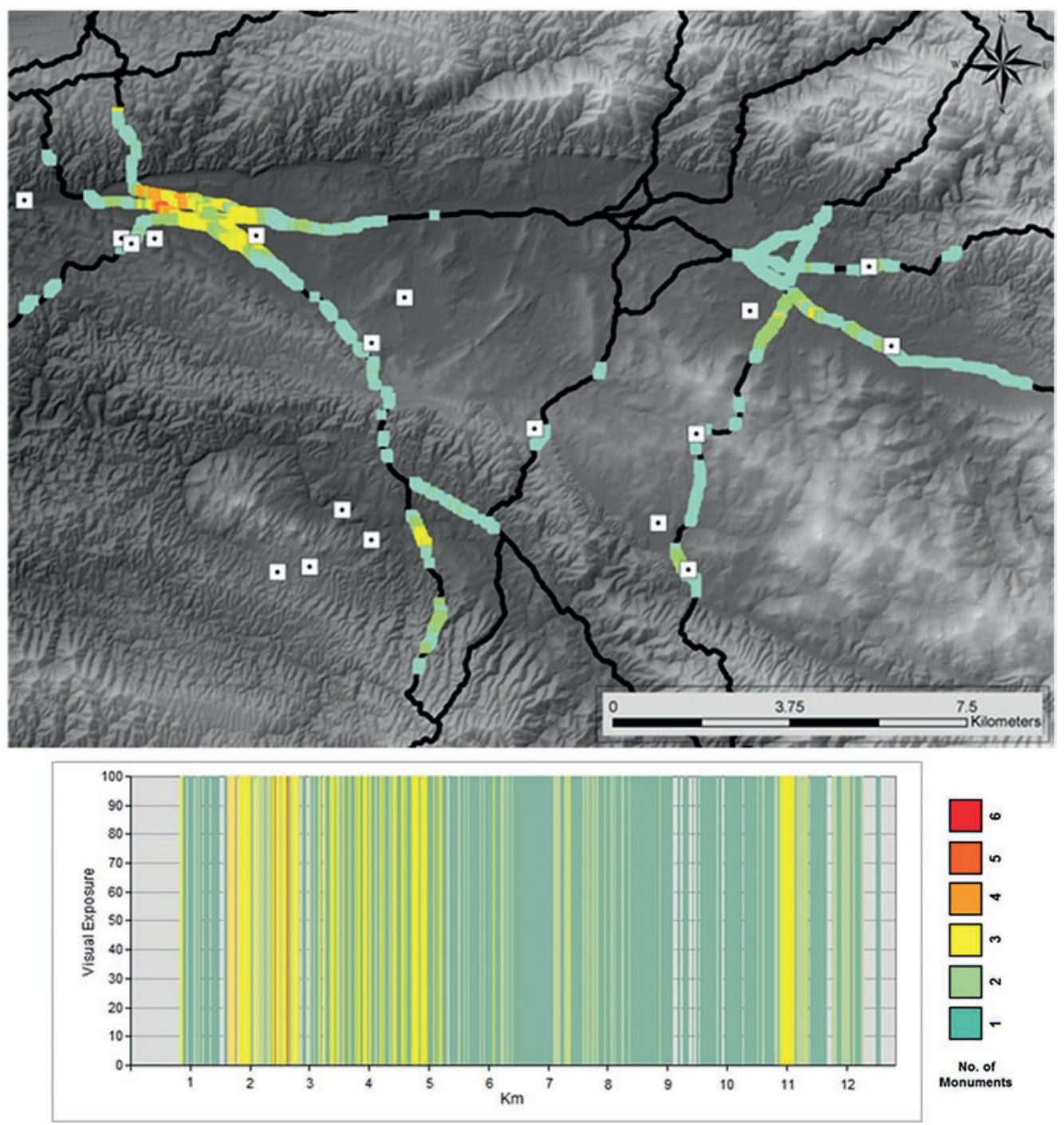

Fig. 12 a) Segments in the natural corridors from which the megaliths are visible. b) Cumulative visual exposure to all megalithic monuments from natural corridors of Aroche. 

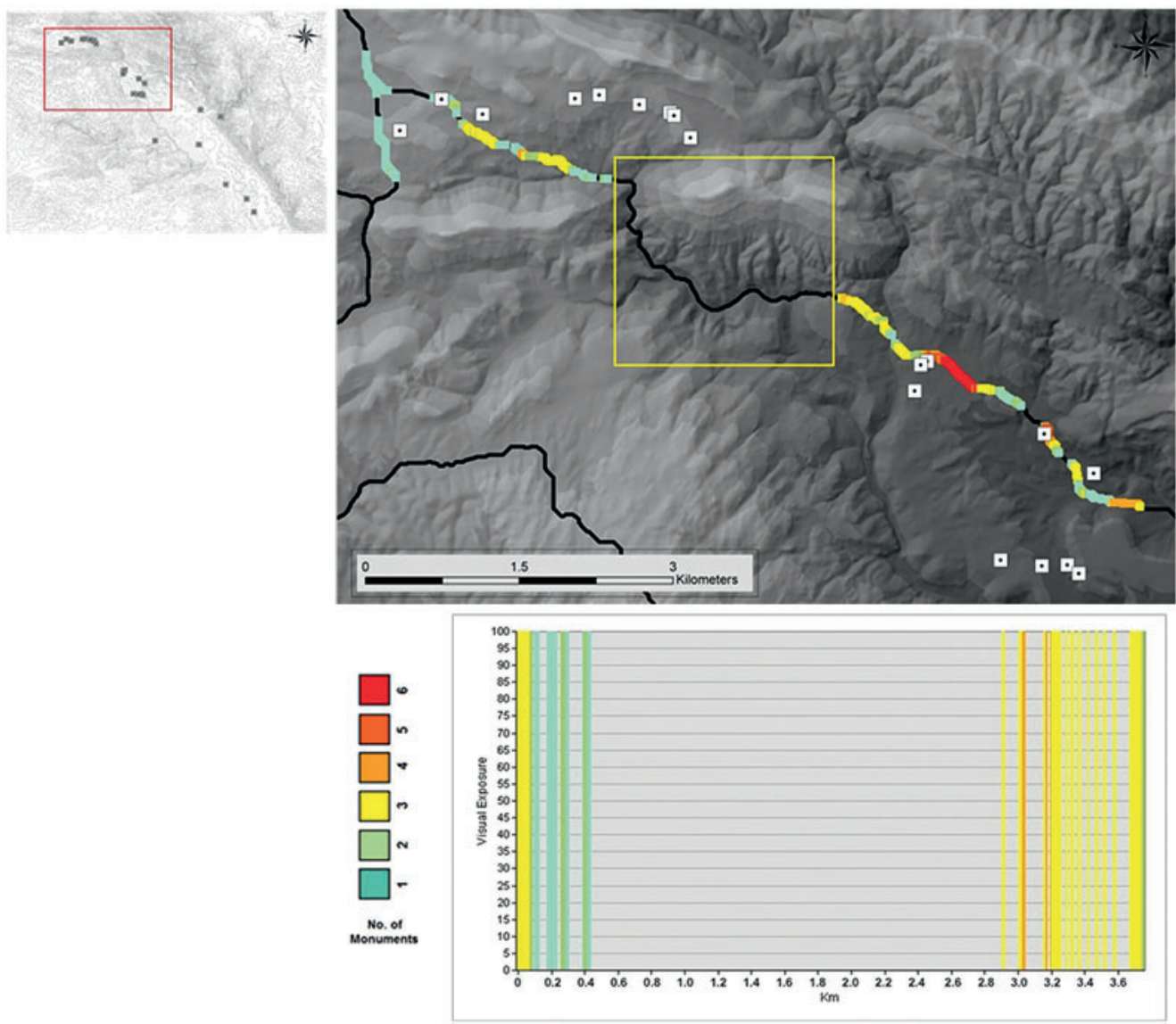

Fig. 13 | Visual exposure of the megalithic groups of San Bartolomé and Dolmen de Palacio III from a segment of the natural corridor that runs along the transhumance route of Cordel del Pedroso.

their significance in terms of the creation of a funerary and symbolic landscape, where the visual accessibility of the monuments seem to have had great importance. This is supported by the results obtained by the statistical test already mentioned, which was conducted in order to investigate directional viewsheds. This analysis showed a significant relationship in most of the groups and that the majority of the dominant directions in the fields of view from monuments are related to a natural corridor or to a transhumance route (Figure I3). However, in terms of terrestrial navigation this could be interpreted in a different way. Although the megaliths in many cases are quite well distributed along the main corridors, many of them are clustered (Figure I3). Whether or not they are all contemporary, in neither case would it have been necessary to have several waypoints very close to each other if one of them was already visible from the corridor. In this manner, the adjacent location of the monuments is perhaps more related to a symbolic recognition of particular 


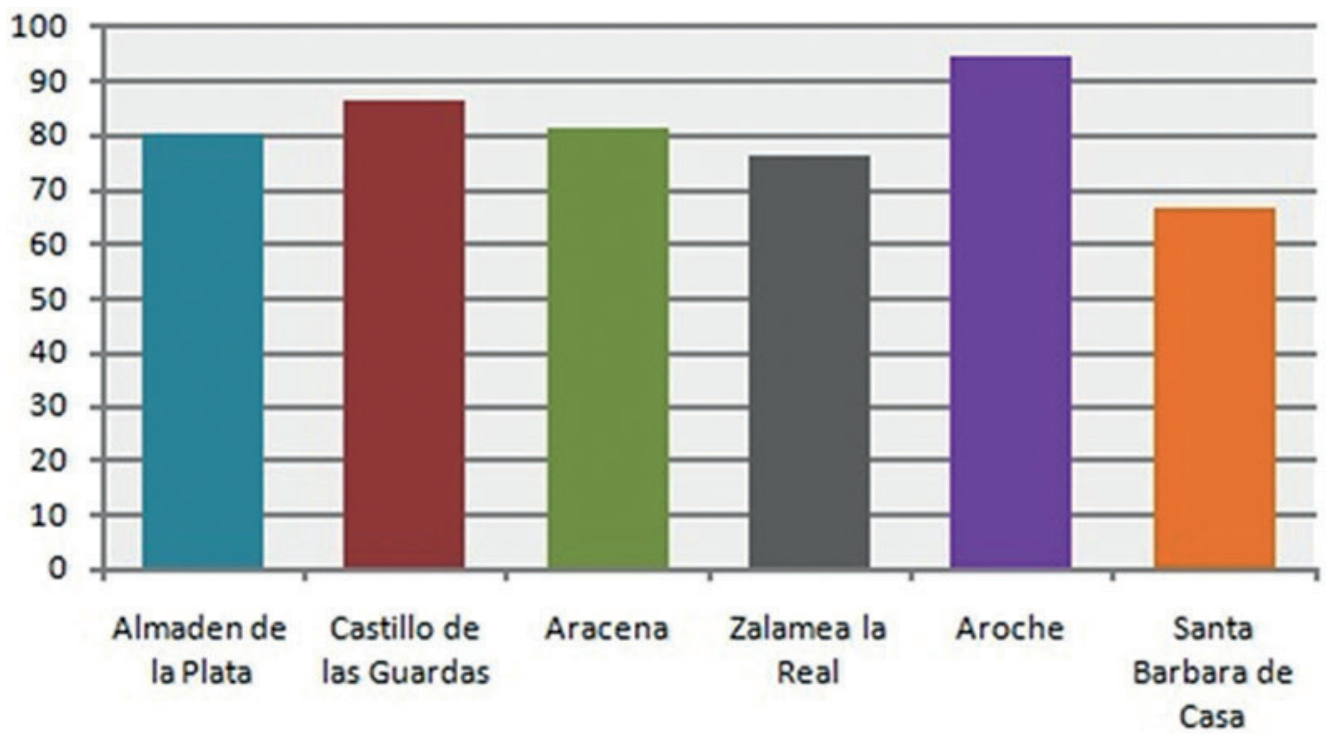

Fig. 14 | Percentages per group of monuments that present a field of view with a dominant direction towards natural corridors.

places that acted as mnemonic markers for a number of groups, families or households, but not necessarily as waypoints.

Regarding the directional viewsheds, the general results were very interesting. Although in the first statistical analysis the relationship between general visibilities and the corridors in some of the groups could not be confirmed, the tests exploring the specific dominant directions in the fields of view of the monuments and their possible connection to corridors was statistically significant. This was the case in all groups with the exception of Santa Bárbara de Casa, where the test could not be carried out due to the small sample. A closer look at the individual results of this analysis confirms that in 5 of the 6 groups, more than $80 \%$ of the monuments exhibit fields of view in which the dominant directions are the ones that coincide with the natural corridors. Again, this is the case in all groups with the exception of Santa Bárbara de Casa, where the dominant directions are related to a natural corridor in only $66.66 \%$ of the monuments. While in Almadén de la Plata $80 \%$ of the megaliths present a relationship between predominant direction of view and corridors, for Castillo de las Guardas the figure is $86.36 \%$. In the case of Aracena the coincidence is $8 \mathrm{I} .25 \%$, for $\mathrm{Za}$ lamea la Real $80.95 \%$ and for Aroche $94.44 \%$ (Figure I4). These results point to the idea that, towards the Copper Age, the majority of the monuments within the sierra were built in locations from which natural corridors were visible. In fact, the results suggest that locations with a dominant view oriented to the corridors were preferred (Figure I5).

The modified Higuchi viewsheds reaffirmed the observations made previously, which pointed to a close visual relationship between monuments and corridors. It was of great in- 

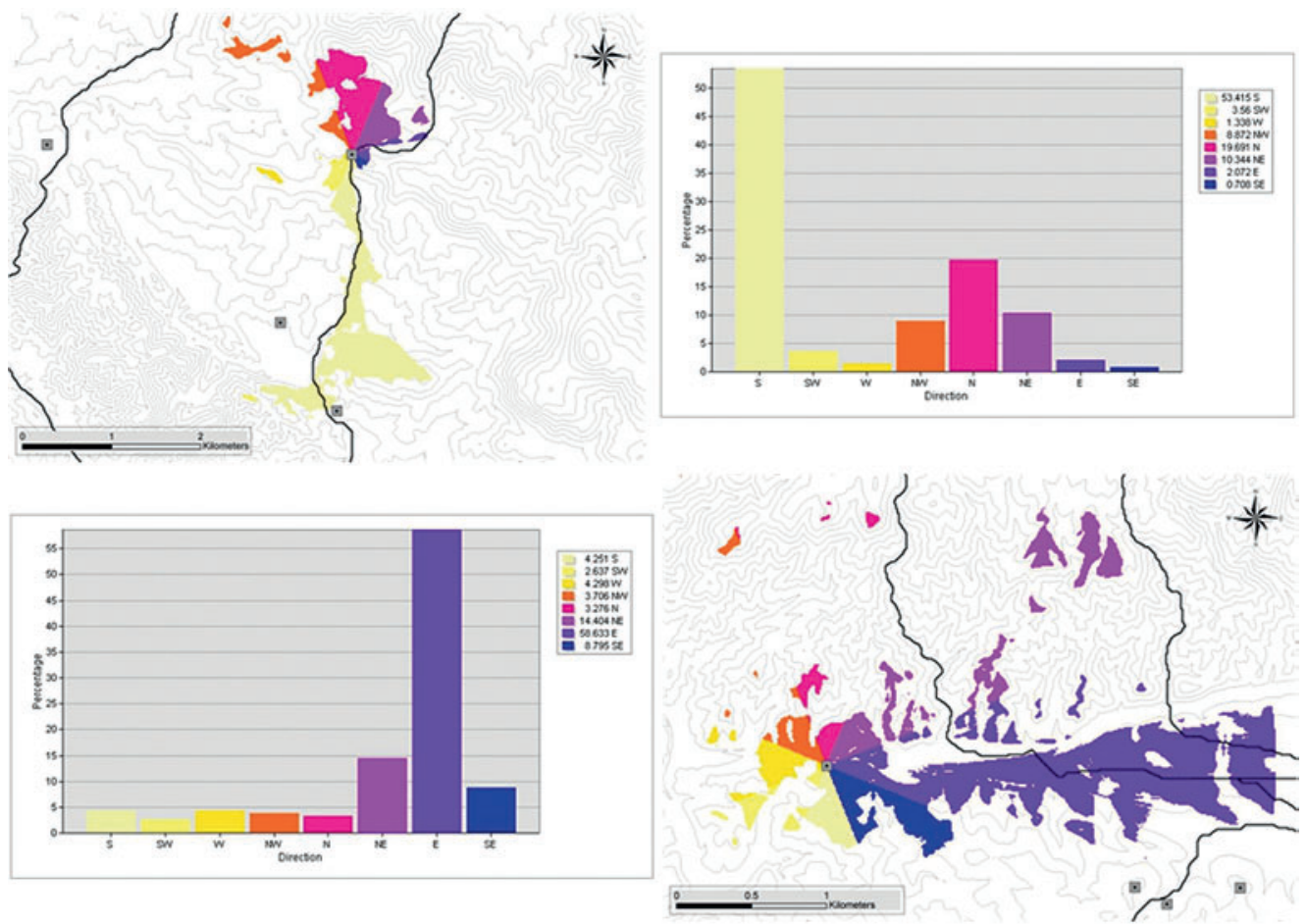

Fig. 15 | Notice the coincidence between the dominant view direction of La Portilla (above) and Pasada del Abad in Aroche (below) with natural corridors.

terest to observe that the majority of the natural corridors fall in what we defined as a visual Middle Range (Figure I6). This seems to be consistent also with the visibility of historical routes, where, as in the previous case, the majority also fall in this range. Nevertheless, there seems to be a closer relationship between monuments and natural corridors than between monuments and historical routes (Figure I7). It is also worth mentioning that, although the number of natural corridors that fall in the visual Short Range is lower, in the majority of the groups there is still a very high coincidence between corridors and monuments where in up to $66.66 \%$ of the cases a natural corridor passes through the shortest range. This is relevant because a close visual proximity to the corridors implies a greater chance of monuments being visible, and therefore that they could be used as waypoints. However, a more consistent relation to the Middle and Long Ranges is observed, and this seems to suggest that there was an intentional relationship of proximity between them. This is also supported by the fact that even in flatter and broader landscapes like the Viar Valley (Almadén de la Plata, Group I) in which the options about where to walk are very wide, late prehistoric societies of this region chose to locate their monuments at close visual ranges to natural corridors. As said, this is observed in the majority of the cases and this relationship could be associated with the way herding trips were conducted and the way that, 

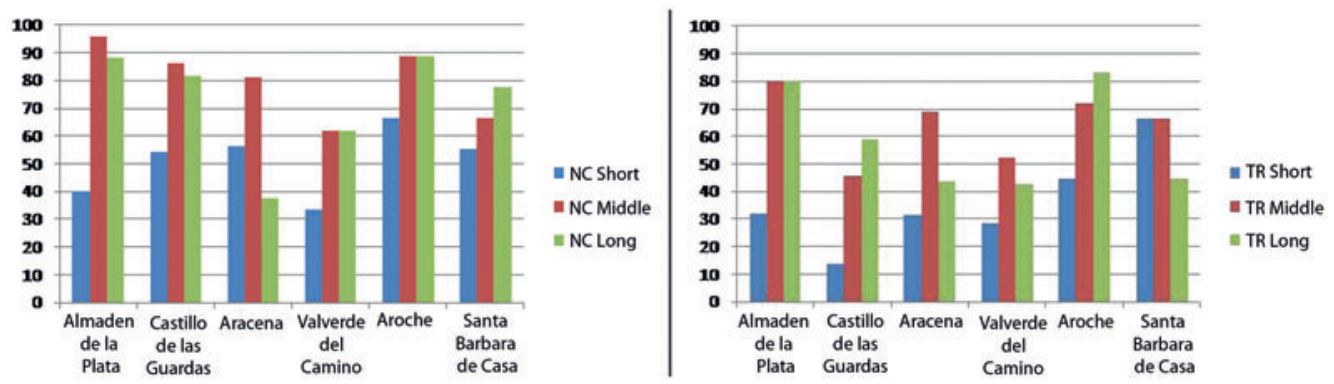

Fig. 16 | Results of the Higuchi Viewsheds: a) Percentage of coincidence between natural corridors and visual distance ranges established and b) between historical transhumance routes and visual distance ranges.

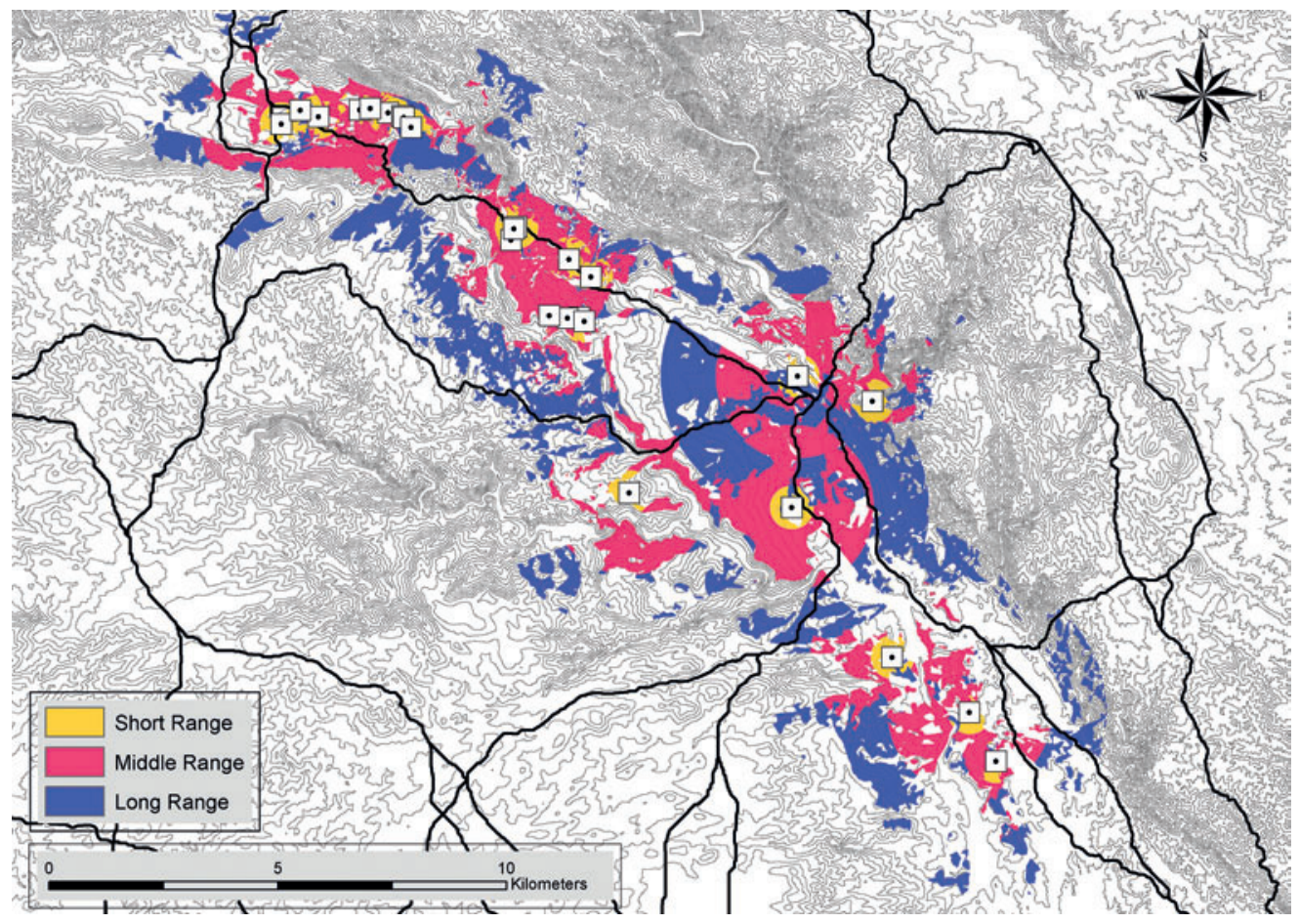

Fig. 17 | Notice the coincidence between the dominant view direction of La Portilla (above) and Pasada del Abad in Aroche (below) with natural corridors. 
as places to visit during these journeys, the visibility of symbolic places in relation to corridors became important. It is very interesting to note that other research (Galán Domingo / Ruíz-Galvez 200I; Murrieta-Flores 20I2a; 20I3) has suggested that megaliths may have also served as landmarks at fords and mountain passes, and this observation seems to be strengthened by this analysis.

\section{Conclusion}

The assessment of the use of megaliths as waypoints has proved a difficult task as the models are relatively simple and the variables to take into account are complex. However, it can be said that the experiments were successful in the identification of a series of interesting patterns. The relationships observed between dominant directions in the fields of view and corridors in the majority of the groups, and the high coincidence between general visibilities and pathways, point to the idea that monuments were effective landscape markers. However, they seem not to have been built with a focus on terrestrial navigation. It is certain that there is a visual relationship between the monuments and natural corridors, and people familiar with this landscape may have been able to locate them easily. Although there is no single corridor where monuments could be regarded as part of a "complete" visual system in terms of continuous visibility, it must be also taken into account that many other features in the landscape may have acted as intermediate waypoints, such as characteristic topographical features or trees. In this manner, it is acknowledged that, with information such as verbal accounts, foreigners too may on some occasions have been able to use them as points of reference while navigating through the landscape. In those terms, they may have been used as waypoints too.

What seems to be certain is that the monuments marked vistas for people moving along the corridors. This seems to be confirmed by the fact that the megaliths are seen more often from the corridors than are other points in the landscape, and because the lengths of the segments from which they are visible within the paths are considerably larger. This outcome is reinforced by the results from the directional viewsheds. The fact that the dominant directions in the fields of view of the megaliths are the ones oriented towards the natural corridors suggests that the visibility of the monuments from them and the other way around was regarded as important in some sense. In this manner, the reason why these two features were visually and spatially connected could lie in the symbolic role that they probably played within pastoral orbits (Murrieta-Flores 20I2a; 20I3). While carrying out these cyclical movements, mobile herding societies visit places they regard as significant in terms of symbolism and memory. These places are normally related to their seasonal cycles, and therefore they are located within their areas of movement. Some of them are visited through several generations and different groups may also have places in common where they can meet to exchange news, celebrate festivities, conduct commerce or 
marriages or simply spend time with each other. Furthermore, the link between monuments and movement may be connected to the idea of permanence, helping to mark the pastoral orbits of different groups. In this sense, the association of monuments and corridors may find its explanation in the symbolic meaning of these sites and their use as landscape markers over generations. The possible meaning of the megaliths as the "houses" of the ancestors could have played an important role in the visits established during the pastoral circuits, where the long use of sites like Palacio III in Almadén de la Plata or Valdelinares in Aracena may constitute testimony of this.

Although it is clear that distinctive locations with particular characteristics were chosen to build the megaliths in this region, it is also interesting to observe that in some cases they are close also to the sources of material from which the orthostats that compose them were taken. This is the case with monuments like Valdelinares in Aracena (Romero Bomba 200I, 377). There seems thus to be a component of economy and practicality in the choice of these places, but the importance of this factor in determining the selection of the sites can only be explored further through detailed study of the sources of building materials. In addition, it could be said that in many cases the monuments seem to be located near rivers and fords. While as part of a herding itinerary these locations would have many convenient qualities in marking sources of water and river crossings, there could also be a symbolic, where the monument commemorates not only ancestors, but also the importance of movement in their way of life. It is of great interest to observe that while settlements seem to be seasonal, the only permanent features are precisely these monuments, which, being located along natural corridors, could have celebrated the cycles of life and the temporal character of their actions, in which movement knit together all meanings and representations.

Therefore, although monuments may not have acted as waypoints in the same manner as the Roman miliarium did, it is very possible that they acted as landmarks in the same way that other, later societies would recognize the architecture of their own times. Just as a pilgrim knows her parish and could identify a Christian church even if far away from home, it is possible that prehistoric communities utilized monuments as markers of important places within their landscape and, even if they may have occasionally served as a point of reference for terrestrial navigation, it is unlikely that all of them functioned as such, so as to form waypoints within travel "itineraries."

The location of important symbolic places throughout cultures and times has usually been attached to particular events, beliefs or social memories. Although nowadays the specific meanings of megaliths escape us, it is interesting to observe that we can still recognize in their locations aspects that seem to have been of importance. The constant observation of a spatial relationship between megalithic monuments and natural corridors could be something specific to the mountain environment of Sierra Morena. However, this connection may be related to the dynamics of these societies' daily life. It is possible that hunting and herding itineraries were formed over time, where contacts with different groups made 
possible a "unified" idea in the symbolism of a megalithic landscape, which at the same time took a distinctive and particular character in each region. This seems to be the case in the western Sierra Morena, where the megalithic phenomenon as well as other archaeological evidence is testimony of the contact between regions. Nevertheless, these contacts seem not to be very extensive and the general day-to-day dynamics probably had a more local nature. This does not mean that they did not actually have extensive contacts with other regions. Several stone tools and green stones such as variscite have been found in other Copper Age sites and they may have their origin in western Sierra Morena (Linares Catela et al. 2010; Linares Catela / Odriozola Lloret 20II).

As said before, the differences observed in settlement patterns, as well as in sizes and styles of construction of the megalithic monuments between regions such as the Guadalquivir Valley and Sierra Morena, seem to support the idea not only of a differentiation in demographic numbers and access to resources, but possibly also in ideology and the construction of a symbolic landscape. It even seems possible to differentiate between regions within western Sierra Morena. However, what they may have in common is that their megaliths were built by groups formed from several families and the locations selected were always near to natural corridors and possibly related to their herding itineraries. In this manner, during hunting and herding journeys, the places once regarded as special were chosen to become sites with an enduring character within social memory, where the megaliths would effectively become a physically permanent station among different groups, marking the space symbolically.

Later, towards the Bronze Age, the dynamics seem to change with the establishment of more permanent settlements like El Trastejón (Aracena). The de-monumentalization of funerary practices and the change to individual tombs marked a very significant transformation of the monuments in terms of social meaning. Nevertheless, in terms of cosmology, these structures and places were still regarded as important in western Sierra Morena. This is evident in monuments like Valdelinares (Aracena) which, due to its dimensions and construction system, could be regarded as related to a later period during the Copper Age, and closer to the megalithic cists. The reuse through many generations of these monuments and sites, like Valdelinares, Palacio III (Almadén de la Plata), El Pozuelo (Zalamea la Real), El Trastejón and La Papúa (Aracena), are testimony of their role as markers and sites of power within the landscape. However, although there seems to be continuity in the funerary patterns, where monuments were reused or new ones were still located very near to natural corridors, this coincidence decreased. Gradually, groups transformed into societies where individuals had more weight, a phenomenon that emerged along with an increasing social inequality. The apparent establishment of a stronger mobile tradition in terms of extended networks, and probably the increase in commerce and exchange, seem to be the reasons why we can observe a closer and growing spatial relationship between settlements and corridors towards the Early and the Late Bronze Age. With the presence of permanent settlements and the development of a society with more social inequality, both settlement 
and funerary spatial patterns changed. The way of carrying out the pastoral orbit probably did not involve families anymore, but one or a few members, and, while the funerary sites were possibly part of the itineraries, the settlements seem to have taken on a more important role within them (Murrieta-Flores 2013).

\section{References}

Andrés Rupérez, M.T. (1999)

"Los caminos y los sepulcros megalíticos", in: M.A. Magallón Botaya (ed.), Caminos y comunicaciones en Aragón, Zaragoza: Institución Fernando el Católico.

Branting, S.A. (2004)

Iron Age Pedestrians at Kerkenes Dag: An Archaeological GIS-T Approach to Movement and Transportation, The State University of New York, Buffalo.

Bueno Ramírez, P. / Piñón, F. / Prados, L. (1985)

"Excavaciones en el Collado de Sejós (Valle de Polaciones, Santander). Campaña I982", in: Noticiario Arqueológico Hispanico 22, 27-53.

Bueno Ramírez, P. (1987)

"El megalitismo en Extremadura. Estado de la cuestión", in: El megalitismo en la Península Iberica, IbéricQll, 73-84.

Chapman, R. (1979)

"Transhumance and Megalithic Tombs in Iberia", in: Antiquity 53, I50-I52.

Chapman, R. (198I)

“The Emergence of Formal Disposal Areas and the 'Problem' of Megalithic Tombs in Prehistoric Europe”, in: R. Chapman / I. Kinnes / K. Randsborg (eds.), The Archaeology of Death, Cambridge, 7I-8I.

Criado Boado, F. / Fábregas Valcarce, R. / Vaquero Lastres, J. (I990-I99I)

"Concentraciones de túmulos y vías naturales de acceso al interior de Galicia", in: Portugalia II-I2, 27-38.

Criado Boado, F. / Fabregas Valcarce, R. / Vaquero Lastres, J. (1994)

"Regional Patterning among the Megaliths of Galicia (NW Spain)", Oxford Journal of Archaeology I3(I), 33-47.

Criado Boado, F. (1993)

"Visibilidad e interpretación del registro arqueológico", in: Trabajos de Prehistoria 50, 39-56.

Eguileta Franco, J.M. (1994)

Megalitismo e Calcolítico na Baixa Limia galega, Santiago de Compostela.

Ehlers, E. / Kreutzmann, H. (2000)

"High Mountain Ecology and Economy. Potential and Constraints", in: E. Ehlers / H. Kreutzmann (eds.), High Mountain Pastoralism in Northern Pakistan, Stuttgart, 9-36. 
Fábrega Álvarez, P. (2006)

"Moving without Destination. A Theoretical, GIS based Determination of Routes (Optimal Accumulation Model of Movement from a Given Origin)", in: Archaeological Computing Newsletter 64, 7-II.

Fábrega Álvarez, P. / Parcero Oubiña, C. (2007)

"Proposals for an Archaeological Analysis of Movement and Pathways", in: Archeologia e Calcolatori I8, I2I-I4O.

Fairén Jiménez, S. (2004)

“¿Se hace camino al andar? Influencia de las variables medioambientales y culturales en el cálculo de caminos óptimos mediante SIG”, in: Trabajos de Prehistoria 6I(2), 25-40.

Fiz, I. / Orengo, H. A. (2008)

"Simulating Communication Routes in Mediterranean Alluvial Plains", in: A. Posluschny / K. Lambers / I. Herzog (eds.), Layers of Perception. Proceedings of the 35th International Conference on Computer Applications and Quantitative Methods in Archaeology (CAA), Berlin, Germany, April 2-6 2007, Bonn, 316-32I.

Fleming, A. (1973)

"Tombs for the Living", Man 8(2), I77-193.

Galán Domingo, E. (1993)

Estelas, paisaje y territorio en el Bronce final del Suroeste de la Península Ibérica, Complutum (3), I5-IIO.

Galán Domingo, E. / Martín Bravo, A.M. (I991-I992)

"Megalitísmo y zonas de paso en la cuenca extremeña del Tajo", Zephyrus 44-45, I93-205.

Galán Domingo, E. / Ruíz-Gálvez, M. (200I)

"Rutas ganaderas, transterminancia y caminos antiguos. El caso del Occidente Peninsular entre el Calcolítico y la Edad del Hierro", in: J. Gómez-Pantoja (ed.), Los rebaños de Gerión. Pastores $y$ transhumancia en Iberia antigua $y$ medieval, Madrid, 279-3II.

García Sanjuán, L. / Vargas Durán, M.A. (2002)

"Prospecciones de superficie en Almadén de la Plata (Sevilla)", in: Anuario Arqueológico de Andalucía I991, 258-270.

García Sanjuán, L. / Vargas Duran, M. / Wheatley, D. (2002)

Zona de afección del Embalse de Los Melonares (Sevilla). Prospección Arqueológica Superficial Y Delimitación de Elementos de Carácter Patrimonial. Campañas Agosto-Septiembre 2001 y Abril 2002. Informe, Universidad de Sevilla, Sevilla.

García Sanjuán, L. / Vargas Durán, M.A. / Wheatley, D. (2004)

"Prospecciones de superficie en la zona de afección del embalse de Los Melonares (Almadén de la Plata, El Pedroso y Castilblanco de los Arroyos, Sevilla)", in: Anuario Arqueológico de Andalucía 200I, 3 (Actividades de Urgencia), 962-972.

García Sanjuán, L. / Metcalfe-Wood, S. / Rivera Jiménez, T. / Wheatley, D. (2006)

"Análisis de pautas de visibilidad en la distribución de monumentos megalíticos de Sierra Morena Occidental”, in: I. Grau Mira (ed.), La aplicación de los SIG a la Arqueología del Paisaje, Alicante, I8I-200. 
García Sanjuán, L. / Wheatley, D. / Fabrega Alvarez, P. / Hernandez Arnedo, M. / Polvorinos del Rio, A. (2006)

"Las Estelas de Guerrero de Almadén de la Plata (Sevilla). Morfología, Tecnología y Contexto", in: Trabajos de Prehistoria 63(2), I35-I52.

García Sanjuán, L. (20II)

"The Warrior Stelae of the Iberian South-west: Symbols of Power in Ancestral Landscapes", in: T. Moore / L. Armada Pita (eds.), Atlantic Europe in the First Millennium BC: Crossing the Divide, Oxford, 534-557.

Golledge, R.G. (1999)

Wayfinding Behavior: Cognitive Mapping and Other Spatial Processes, Baltimore.

Gómez Vila, J. (2005)

"Caminos y túmulos. Aproximación al estudio de los caminos megalíticos en el noroeste peninsular", in: P. Arias Cabal / Roberto Ontañon Peredo / Cristina García-Monco Piñero (eds.), Actas del III Congreso del Neolítico en la Península Ibérica, Santander, 405-4I2.

Higuchi, T. (1983)

Visual and Spatial Structure of Landscapes, Cambridge, MA.

Hurtado Pérez, V. / García Sanjuán, L. / Hunt Ortiz, M. A. (eds.) (20II)

El Asentamiento de El Trastejón (Huelva). Investigaciones en el Marco de los Procesos Sociales y Culturales en la Edad del Bronce en el Suroeste de la Península Ibérica, Sevilla.

Linares Catela, J.A. / Odriozola Lloret, C. / Hurtado Pérez, V. (20I0)

"Variscite Source and Source Analysis: Testing Assumptions at Pico Centeno (Encinasola, Spain)", in: Journal of Archaeological Science 37, 3I46-3157.

Linares Catela, J.A. / Odriozola Lloret, C. (20II)

"Cuentas de collar de variscita y otras piedras verdes en tumbas megalíticas del Suroeste de la Península Ibérica. Cuestiones acerca de su producción, circulación y presencia en contextos funerarios", in: L.S. García Sanjuán / C. Scarre / D. Wheatley (eds.), Exploring Time and Matter in Prehistoric Monuments: Absolute Chronology and Rare Rocks in European Megaliths. Proceedings of the 2nd EMSG Meeting (Seville, November 2008), Seville, 335-369.

Llobera, M. (2000)

"Understanding Movement: A Pilot Model towards the Sociology of Movement", in: G. Lock (ed.), Beyond the Map. Archaeology and Spatial Technologies, Amsterdam.

Llobera, M. (2007b)

"Reconstructing Visual Landscapes", in: World Archaeology 39(I), 5I-69.

Llobera, M. / Sluckin, T. J. (2007)

"Zigzagging: Theoretical Insights on Climbing Strategies", in: Journal of Theoretical Archaeology 249, 206-2I7.

Mlekuž, D. (20I0)

"Time Geography, GIS and Archaeology", Paper Presented at the 38th Conference on Computer Applications and Quantitative Methods in Archaeology, April 20I0, Granada, Spain. 
Moran, P. (1950)

Notes on Continuous Stochastic Phenomena. Biometrika, 37,I7-23.

Murrieta Flores, P.A. (2007)

"Mobility, Transhumance and Prehistoric Landscape. A GIS Approach to the Archaeological Landscape of Almadén de la Plata in Andalucía, Spain", masters thesis, University of Southampton.

Murrieta-Flores, P. (2010)

"Travelling in a Prehistoric Landscape: Exploring the Influences that Shaped Human Movement”, in: B. Frischer / J. Webb Crawford / D. Koller (eds.), Making History Interactive. Computer Applications and Quantitative Methods in Archaeology (CAA). Proceedings of the 37th International Conference, March 22-26, 2009, Williamsburg, Virginia, United States of America. Oxford, 258-276.

Murrieta-Flores, P. (20I2a)

"Understanding Movement during Late Prehistory through Spatial Technologies: The Role of Natural Areas of Transit in South-Western Iberia", in: Trabajos de Prehistoria 69(I), II4-I33.

\section{Murrieta Flores, P. (20I2b)}

"Travelling through Past Landscapes. Analysing the Dynamics of Movement during Late Prehistory in Southern Iberia with Spatial Technologies", doctoral thesis, University of Southampton.

Murrieta-Flores, P. (2013)

"Space and Temporality in Herding Societies: Exploring Dynamics of Movement during Iberian Late Prehistory", in: S. Souvatzi/ A. Hadji (eds.), Space and Time in Mediterranean Prehistory, London, I96-213.

Murrieta-Flores, P. / Wheatley, D. / García Sanjuan, L. (2011a)

"Movilidad, trashumancia y paisaje prehistórico: Estudio del paisaje arqueológico de Almadén de la Plata, Andalucía a través de un SIG", in: V. Mayoral Herrera / S. Celestino Pérez (eds.), Sistemas de Información Geográfica Y Análisis Arqueológico del Territorio, Actas del V Simposio Internacional de Arqueología de Mérida. Mérida, 7-Io de Noviembre de 2007. Mérida, $4 \mathrm{II}-423$.

Murrieta Flores, P. / Wheatley, D. / García Sanjuán, L. (20IIb)

"Antes de los mapas: Navegación y orientación terrestre en la Prehistoria Reciente Ibérica", in: PH: Boletín del Instituto Andaluz del Patrimonio Histórico I9(77), 85-88.

Ogburn, D.E. (2006)

"Assessing the Level of Visibility of Cultural Objects in Past Landscapes", in: Journal of Archaeological Science 33, 405-4I3.

Pellicer Catalán, M. / Hurtado Pérez, V. (I980)

El poblado metalúrgico de Chinflon (Zalamea la Real, Huelva), Sevilla.

Pérez Macías, J.A. (1987)

Carta arqueológica de los Picos de Aroche, Huelva. 
Pérez Macías, J.A. (1996b)

"El Cerro de las Abejas (Rosal de la Frontera, Huelva). La expresion de un territorio de la Edad del Cobre", in: I Jornadas Transfronterizas sobre La Contienda Hispano-Portuguesa (junio de 1995), Aroche, II3-II5.

\section{Pérez Macías, J.A. (1994)}

"El yacimiento Calcolítico del Cerro del Brueco. Propuesta para una secuencia de la Edad del Cobre en los Picos de Aroche", in: Arqueología en el Entorno del Bajo Guadiana, Huelva, II9-I48.

Pérez Macías, J.A. (1986)

"La ocupación prehistórica de la Peña de arias Montano (Alajár, Huelva)", in: Primeras Jornadas de Patrimonio de la Sierra de Huelva, 77-97.

Pérez Macías, J.A. (1996)

Metalurgia extractiva prerromana en Huelva, Huelva.

Pérez Macías, J.A. (2010)

"Un asentamiento del III Milenio A.C. en La Lapa (Encinasola, Huelva)", XXII Jornadas de la Comarca de la Sierra. Higuera de la Sierra (Huelva), Higuera de la Sierra, 269-285.

Piñón Varela, F. (1987)

"El Cabezo de los Vientos, La Zarcita (Santa Bárbara de Casa): un poblado Calcolítico fortificado en el NE de la provincia de Huelva. Campana de I985", in: Anuario Arqueológico de Andalucía I985, 2, 272-278.

Piñón Varela, F. (1988)

"El 'Grupo de Aroche': sepulcros de cámara poligonal y corredor en la Sierra de Huelva”, in: II Jornadas de Patrimonio de la Sierra de Huelva, Cortegana, 237-277.

Renfrew, C. (1976)

"Megaliths, Territories and Populations", in: S.J. De Laet (ed.), Acculturation and Continuity in Atlantic Europe, Mainly during the Neolithic period and the Bronze Age, Bruges, I98-220.

Romero Bomba, E. (200I)

"La intervención arqueológica en la estructura megalítica de Valdelinares (Zufre, Huelva)", in: Anuario arqueológico de Andalucía I997, 3, 376-383.

Saxe, A. (1970)

"Social Dimensions of Mortuary Practices", unpublished doctoral dissertation, University of Michigan, Ann Arbor.

Villoch Vázquez, V. (200I)

"El emplazamiento tumular como estrategia de configuracion del espacio social. Galicia en la prehistoria reciente", in: Complutum I2, 33-49.

Walker, M.J. (1983)

"Laying a Mega-myth: Dolmens and Drovers in Prehistoric Spain", World Archaeology I5(I: Transhumance and Pastoralism), 37-50. 
Wheatley, D. (1995)

"Cumulative Viewshed Analysis: A GIS-based Method for Investigating Intervisibility, and its Archaeological Application", in: G. Lock, and Z. Stancic (eds.), Archaeology and GIS: A European Perspective, London.

Wheatley, D. / Gillings, M. (2002)

Spatial Technology and Archaeology. The Archaeological Applications of GIS, London.

Wheatley, D.W. / García Sanjuán, L. / Murrieta Flores, P. / Márquez Pérez, J. (20I0)

"The Megalithic Phenomenon in Southern Spain: Approaching the Landscape Dimension", Oxford Journal of Archaeology 29(4), 387-405. 
